\title{
RETHINKING Public LAW IN A TIME OF DEMOCRATIC DECLINE
}

\author{
Sir Geoffrey Palmer $Q C^{*}$
}

\begin{abstract}
The 13 separate segments of this article are designed to explore the consequences for New Zealand public law of the global decline of democracy in many parts of the world, although not in New Zealand. The trend towards autocracy is evident in many countries and has been increasing. There was a time when democracy was thought to be inevitable, but that time has passed. Since New Zealand is a small and open society, democratic rot and decline could set in, as it has in other democracies. In order to combat these tendencies, it is necessary to think about the implications of these developments for teaching public law and for the need to bolster education in citizenship, so people can better understand the advantages of democracy, participate in it and feel a commitment to it. Many New Zealanders not born here may not understand the culture, may not have English as their first language and may be discouraged from engagement. New Zealand is increasingly diverse.
\end{abstract}

The article explores the recent history of the United States and to a lesser extent, the United Kingdom, to discern the tendencies at work in those democracies. Returning to the fundamental elements of public law, it is suggested that the analysis begins with the nature and character of the state, followed by international law. Then it is argued it is necessary in the New Zealand context to examine the situation of Māori, Te Tiriti o Waitangi, the activities of the settler governments and the remaining consequences of colonisation. There appears at this time to be an opportunity to more significantly recognise indigenous Māori culture. From there, an examination of some important principles of political philosophy is provided. This leads to a summary of the main types of government that are available for any state. Then are set out the main political ideologies that often impel political actors. The changes in democratic practice that have resulted from the digital revolution are then examined with the effects upon political parties and how they have changed New Zealand. The manner in which public opinion can be manipulated and the need to become literate in politics and political practice is emphasised. The article concludes with a discussion of public law as an autonomous discipline and a final conclusion about what all this means for New Zealand. In the mind of the author, after a long

* Distinguished Fellow, Victoria University of Wellington, Faculty of Law and Centre for Public Law; Global Affiliated Professor, University of Iowa, College of Law. The author is grateful for comments on a draft from Professor Mark Hickford, Sir Kenneth Keith, Associate Professor Dean Knight, Gary Finlay, Bernard Steeds and an anonymous reviewer. 
career in public law and politics, these separate elements combine into a message about the need for democratic refurbishment and future vigilance in New Zealand.

\section{CHALLENGES TO DEMOCRACY}

This article asks for a broader and more contextual approach to public law in New Zealand, in light of the international evidence of democratic decline. It aims to stimulate a rethink as a consequence. It argues that lawyers should adjust their approach in light of the evidence. This article is also linked to the related plea for more intense and comprehensive education in civics in New Zealand schools and universities. It is especially difficult at law school to teach public law to students who have little grasp of their country's own politics and history. Political literacy is a necessity to understand the New Zealand system of government. The article is not a plea for big constitutional change in New Zealand; that claim has been advanced sufficiently elsewhere. ${ }^{1}$ It does appear, however, that despite the importance of cultural norms and history, a written constitution could protect against political developments of the type that occurred in the United States following the 2020 presidential election result. $^{2}$ There the law, not the conspiracy, prevailed. This article ranges far and wide and it may not be easy for the reader to relate the detail in the various segments to overall theme, although in each section an effort will be made to do that.

Global developments in politics and governance around the world in recent years carry a message for public law: there is a need to re-examine its foundations. From this New Zealand cannot be exempt. ${ }^{3}$ At a time when there is something of a crisis in the confidence in democratic governments, around the planet, although not in New Zealand, we ought to think about the basic issues. ${ }^{4}$ Change is

1 Geoffrey Palmer New Zealand's Constitution in Crisis: Reforming our Political System (John McIndoe, Dunedin, 1992); Geoffrey Palmer and Andrew Butler A Constitution for Aotearoa New Zealand (Victoria University Press, Wellington, 2016); Geoffrey Palmer and Andrew Butler Towards Democratic Renewal: Ideas for Constitutional Change in New Zealand (Victoria University Press, Wellington, 2018); Geoffrey Palmer "The Bill of Rights after Twenty-One Years: The New Zealand Constitutional Caravan Moves on?" (2013) 11 NZJPIL 257; and Geoffrey Palmer "What the Bill of Rights Act Aimed to Do, Why it did not Succeed and How it can be Repaired" (2016) 14 NZJPIL 169.

2 Neil Seigel "Law is Not Enough" (2019) 45 Ohio Northern U L Rev 197; and Neil Siegel "Political Norms, Constitutional Conventions, and President Donald Trump" (2018) 93 Indiana L J 177.

3 This is not the first time I have tried to reorient public law thinking: Geoffrey Palmer "The New Public Law: Its Province and Function" (1992) 22 VUWLR 1; see also Geoffrey Palmer "Muldoon and the Constitution" in Margaret Clark (ed) Muldoon Revisited (Dunmore Press, Palmerston North, 2004) 167. Two official reports have been produced in recent years, neither of which appears to have produced significant change: Constitutional Arrangements Committee Inquiry to Review New Zealand's Existing Constitutional Arrangements (10 August 2005); Constitutional Advisory Panel New Zealand's Constitution: A Report on a Conversation (November 2013). Both reports expressed concern at the lack of understanding within the community as to how governance works.

4 A C Grayling Democracy and its Crisis (2nd ed, One World, London, 2018); A C Grayling The Good State: On the Principles of Democracy (One World, London, 2020); Steven Levitsky and Daniel Ziblatt How 
inevitable, its rate is accelerating, coping with it requires hard thinking. The policy problems are many. In 1989 Francis Fukuyama announced, after the fall of the Berlin Wall, that mankind had arrived at the end point of ideological evolution. ${ }^{5}$ That end point of history was "the universalisation of Western democracy as the final form of human government." ${ }^{6}$ The superiority of the liberal democratic state had been established.

We know now that view was wrong. The assumption that democracy is inevitable needs to be revisited. Martin Shapiro, a political theorist, wrote in 2003 in relation to democracy that its "political legitimacy is seldom seriously challenged in the contemporary world." ${ }^{7}$ It is challenged now. It is challenged by China - consider its behaviour in Hong Kong and the fact that Xi Jinping (the President of the Peoples' Republic) is no longer subject to term limits. ${ }^{8}$ It is challenged by developments in such countries as Russia, Belarus, Hungary, Poland, Thailand, Turkey, Venezuela, Myanmar and Kyrgyzstan. A tendency toward authoritarianism is clearly discernible. ${ }^{9}$ The number of democracies has declined; democracy is seen to be in retreat. A recent and rigorous 2020 report produced by the Centre for the Future of Democracy at the University of Cambridge concluded: "We found that dissatisfaction with democracy has risen over time, and is reaching an all-time global high, in particular in developed democracies." ${ }^{10}$ Across the globe democracy is in a state of malaise. Dissatisfaction has risen sharply since 2005.

Democracies Die (Viking, New York, 2018); Patrick J Deneen Why Liberalism Failed (Yale University Press, New Haven, 2018); John Keane The Life and Death of Democracy (Simon \& Schuster, London, 2009); Niall Ferguson The Great Degeneration: How Institutions Decay and Economies Die (Allen Lane, London, 2012); Yuval Noah Harari 21 Lessons for the 21st Century (Jonathan Cape, London, 2018); J L Talmon The Origins of Totalitarian Democracy (Mercury Books, London, 1961); and Timothy Snyder On Tyranny-Twenty Lessons from the Twentieth Century (The Bodley Head, London, 2017). See also Tom Gerald Daly "Democratic Decay: Conceptualising an Emerging Research Field" (2019) 11 Hague Journal on the Rule of Law 9; Jack M Balkin "Constitutional democracy in crisis and Constitutional Rot" (2017) 77 Md Law Rev 147; Mark A Graber, Sanford Levinson and Mark Tushnet Constitutional Democracy in Crisis? (Oxford University Press, New York, 2018); David Runciman How Democracy Ends (Profile Books, London, 2019); and Linda Colley The Gun, the Ship, and the Pen: Warfare and the Making of the Modern World (Profile Books, London, 2021).

5 Francis Fukuyama "The End of History and the Last Man" National Interest (Washington DC, Summer 1989).

6 Francis Fukuyama, above n 5, at 3-18. Later expanded into a book: Francis Fukuyama The End of History and the Last Man (Free Press, New York, 1992).

7 Ian Shapiro The State of Democratic Theory (Princeton University Press, Princeton, 2006) at 146.

8 Clive Hamilton and Mareike Ohlberg Hidden Hand: Exposing How the Chinese Communist Party is Reshaping the World (Hardie Grant Books, Melbourne, 2020). Compare with Daniel Immerwahr How to Hide an Empire - A History of the Greater United States (Farrar, Straus \& Giroux, New York, 2019.)

9 Details for each of the countries mentioned here can be found in the citations in fn 10 .

10 RS Foa and others The Global Satisfaction with Democracy Report 2020 (Cambridge, Centre for the Future of Democracy, 2020) at 1 . The report states there has been an especially acute crisis of democratic faith in the Anglo-Saxon democracies, at 18. Dissatisfaction has doubled. New Zealand, however, has avoided the 
The decline does not have to be accompanied by a coup d'état or revolution. It can be achieved by restricting freedom of speech and freedom of assembly or weakening the rule of law by undermining the judiciary or replacing them. The levels of corruption and cronyism within governments contribute to the decay and rot. The increasing tendency of people to look to governments to protect them from the Covid-19 pandemic provides an opportunity for governments that are so minded to gather for themselves greater amounts of power.

New Zealand stands against the trend. In the October 2020 general election, in the year of Covid19 , returned a majority single party government under the leadership of the Rt Hon Jacinda Ardern for the first time since the mixed-member proportional system of electoral law began to work in 1996. ${ }^{11}$ Strong restrictions were imposed by the Government on many personal freedoms, for example orders to stay at home and not go out for a significant period, to combat the virus. ${ }^{12}$ The Prime Minister and the Labour Party were rewarded by a handsome political victory in the October 2020 general election, in particular it would seem for a successful set of policies that largely kept Covid19 out and the death rate low, compared with almost every other country. There appears to be little apprehension in New Zealand that Covid-19 restrictions could became a permanent part of the constitutional landscape. ${ }^{13}$ Nevertheless, the dangerous anti-democratic trends that have emerged in

"trajectory of soaring public discontent"; this may be because it is the only country in the group to have adopted a proportional representation electoral system, at 19. See also Freedom House Nations in Transit 2020 - Dropping the Democratic Façade (Washington DC, Freedom House, 2020): this study found that 2018 was the 13th successive year of deteriorating freedoms around the globe. The decline of democracy was alarming with more countries moving toward authoritarian rule. Populist forces were pushing against long held democratic principles. That organisation's latest annual report published in 2021 stated it was the 15th year in a row that it had reported that democracy was going backwards. Three quarters of people who live on earth live in countries where freedom is declining: Freedom House Freedom in the World $<$ https://freedomhouse.org $>$. New Zealand scored 99 per cent out of 100. Sweden, Finland and Norway scored 100 .

11 Political scientists report that New Zealand "is not immune to authoritarian populism" citing Sir Robert Muldoon's tendencies when he was Prime Minister: Jack Vowles and Jennifer Curtin (eds) A Populist Exception? - The 2017 New Zealand General Election (Australian National University Press, Canberra, 2020) at 272. They also found that there was no evidence New Zealand has "been witnessing declining levels of political trust," unlike other countries, at 273. New Zealand is not immune from dubious political practices: Nicky Hager Dirty Politics: How attack politics is poisoning New Zealand's political environment (Craig Potton Publishing, Nelson, 2014); and Peter Griffin "Hit Job: How the PR Campaign to Undermine Public Health Critics of Big Sugar, Big Alcohol and Big Tobacco Turned Dirty - and the Continuing Fight Over Food Politics" New Zealand Listener (New Zealand, 27 March 2021) at 16.

12 See "Legislation and key documents" (28 June 2021) Unite against COVID-19 <https://covid19.govt.nz>.

13 It is interesting in this respect to contemplate the differences between the political cultures of New Zealand and United States as examined by David Hackett Fischer Fairness and Freedom: A History of Two Open Societies - New Zealand and the United States (Oxford University Press, Oxford, 2012). 
other countries could arrive here in the fulness of time, in part due to social media and the digital revolution.

A re-examination of the intellectual foundations upon which the New Zealand system rests should be undertaken. Looking to the future, we do need to understand that democracy can easily be blown off course. Division and polarisation, once they occur, can morph into authoritarian or autocratic government and fan social division. The recent developments among democracies with whom we often compare ourselves need to be taken seriously. While New Zealand does tend to stand out as a beacon of hope, we need to be mindful of destructive tendencies that have emerged elsewhere and have been seen here at times in the past.

It is important, also, not to get romantic about democracy. It is a system with many weaknesses and a substantial literature exists analysing them. ${ }^{14}$ Making decisions is difficult and time consuming. The theory is that the people are in charge, but do their preferences really drive policy? Democracy itself is constantly changing and evolving; it is also prone to decay and rot.

In advancing this claim for a reorienting of public law thinking accompanied by citizenship education, this article is not based on an empirical analysis of what is currently offered at New Zealand law faculties or in ordinary schools. It is influenced by a reading of the course materials for Laws 213 - the yearlong public law course at Victoria University of Wellington's Faculty of Law - in 2019 and $2020 .{ }^{15}$

The materials themselves, of course, cannot capture the richness of the classroom discussion upon them. Law teachers have different techniques and approaches, inevitably. A number of the points made in this article may well have been dealt with to some degree in the current teaching. In 1993 Mai Chen and the writer published a set of cases, material and commentary designed to push out the boat for what is taught. ${ }^{16}$ It covered such topics as parliamentary procedure and processes, the reform of Parliament, the issue of an upper house, the Official Information Act, freedom of expression and the use of the media in politics, the Royal Commission on Electoral law and the need to regulate political parties. There was extensive material also on the Waitangi Tribunal. The present article is

14 The most trenchant recent critique of democracy I have read recently, and it comes with a Roman Catholic angle, is the work of a Belgian historian: Christophe Buffin de Chosal The End of Democracy (Tumblar House, Arcadia, California, 2017). The attacks on the European community, political parties, the deceits involved in elections, democratic politics and the breakdown of ethno-cultural solidarity are significant.

15 The topics included in the materials in four volumes were constitutional framework issues, the monarchy, the prerogative, Imperial legislation, some constitutional history, the electoral system, the rule of law, Dicey, international law, human rights theories and the Bill of Rights and interpretation issues: administrative law and judicial review of administrative action including the Ombudsmen, the Treaty of Waitangi and case law on it and related matters.

16 Mai Chen and Geoffrey Palmer Public Law in New Zealand: Cases, Materials, Commentary and Questions (Oxford University Press, Wellington, 1993). 
not an attack on what is now taught. It is a respectful request to change focus considering the challenges flowing from the international trends of democratic decay and rot. It has long been the view of the writer that policy analysis skills are necessary for senior public lawyers. This is because political discourse is a debate concerning competing priorities and those priorities are set by Cabinet. The processes by which this takes place requires knowledge. ${ }^{17}$

One essential of democracy is trust in government and its institutions by the people on whose behalf it makes decisions. Democracy is a fragile flower and needs to be carefully nurtured, watered and weeded if it is to thrive. A renewed commitment to democracy in an increasingly uncertain world should start with education at all levels. We need also to guard against the dangers of slow degradation and neglect. In order to accomplish that task, people must understand a number of basic concepts that may be insufficiently traversed in schools and the basic public law courses and in political science courses in universities.

These include:

- What is the state and the nature of its legal personality?

- What is the purpose of the state?

- How do states relate to one another and what are the rules?

- What human forms of government exist or have existed?

- What political ideologies are available?

- What does political philosophy say about policy directions to be adopted?

- How does democracy compare with other forms of government?

- How did the New Zealand system develop, how did it treat the indigenous Māori population and what were the influences that drove those developments?

- What are the established elements of the New Zealand political culture with reference to its historical development?

- How do political parties and elections work?

- How is public opinion molded and manipulated in politics?

- How does the media function and how does political communication work in an increasingly digital world?

- How to get things done in this new world?

\section{CIVIC KNOWLEDGE AND COMPOSITION OF THE POPULATION}

The case for increasing the teaching of civics and citizenship education in schools and beyond is based to a degree on the ethnic composition of the New Zealand population and how much it has

17 Geoffrey Palmer "The Law Reform Enterprise: Evaluating the Past and Charting the Future" (2015) 131 LQR 402 at 413-415; see also Nathan Jon Ross "Beyond Skills and Doctrine: The Need for Policy Skills and Interdisciplinarity" (2017) 48 VUWLR 353 
changed over the last thirty years. Some of the demographic facts and projections are important to understanding this issue. New Zealand is a country built on immigration. After Māori migration, the main immigrants from 1840 and for many years thereafter were mainly from the United Kingdom and Ireland.

The 2018 census shows that more than 27.4 per cent of the total population were born overseas, more than a million people. A significant number of them may not have English as their native language. This tends to make the institutions of government less accessible for such communities than it is for those who are steeped in New Zealand's customs, political culture and ways of doing things. ${ }^{18}$

Statistics New Zealand tells us that Asian people will out-number Māori in the mid-2020s. It cannot be assumed the immigrants from many countries will easily understand the unique features of the New Zealand system of government without adequate civic education. ${ }^{19}$ The relevant percentages of ethnic population projections look like this: ${ }^{20}$

\begin{tabular}{|l|l|l|}
\hline & $\mathbf{2 0 1 3}$ & $\mathbf{2 0 3 8}$ \\
\hline European or other & 74.6 & 65.5 \\
\hline Māori & 15.6 & 18.4 \\
\hline Pasifika & 7.8 & 10.2 \\
\hline Asian & 12 & 22 \\
\hline Others & 1.2 & 3 \\
\hline
\end{tabular}

Between 2001 and 2013 there was an increase in Asian communities of 24 per cent and that is likely to continue. (This description includes the Indian subcontinent through to Korea and Taiwan and includes China. It is from China that the greatest growth is expected by 2038. Covid-19 could affect these projections.) These developments have led Professor Spoonley to conclude that New Zealand is one of "the world's most globally super-diverse countries." ${ }^{21} \mathrm{He}$ also reports that Auckland is the fourth most diverse city on the planet in terms of the proportion who are migrants. Super-

18 Paul Spoonley The New New Zealand: Facing Demographic Disruption (Massey University Press, Auckland 2020) at 42.

19 Statistics New Zealand "Ethnic Diversity Projections to rise" (media release, 18 May 2017) <http://nzdot stat.stats.govt.nz>.

20 The percentage projections were created using the information from Statistics New Zealand: see Statistics New Zealand, above n 19.

21 Spoonley, above n 18, at 112. 
diversity has led to private efforts to take measures by way of education to fill the gap. ${ }^{22}$ The Royal Commission of Inquiry into the Christchurch terrorist attack on 15 March 2019 concluded, "There is a lack of cultural and linguistic competence and a poor understanding of the implications of New Zealand's increasingly diverse demographics in Public Sector agencies."23

Many migrants, not just those from Asia but also those who are Pasifika, do not have English as their first language and this is a further obstacle to accessing government institutions. Civic knowledge is vital. Having taught public law a number of times over the years, I have always been worried about the basic state of civic knowledge with which students arrive. Knowledge will empower people. It may help to dispel apathy and encourage people to become active participants in their democracy. An active citizenship can help government serve them better.

There is no empirical evidence known to the writer that establishes what new migrants know or do not know about the system of government in New Zealand compared with people who have been here longer. It seems a reasonable inference that cultural diversity may lead to a lack of civic knowledge.

\section{THE UNITED STATES AND UNITED KINGDOM}

The purpose of this segment of the article is to outline in detail serious issues with democratic decay and rot that have emerged in the United States and the United Kingdom. What has occurred in these democracies helps indicate tendencies which need to be avoided in New Zealand. This is why they are set out in some detail. These two countries have most influenced New Zealand's political and constitutional development. The Anglosphere has lost its mojo. This should put New Zealand on notice to consider its constitutional fundamentals in order to avoid possible future instability. Issues in the future, particularly climate change, could produce significant disruption as the economy is transformed.

The election of Donald Trump to the presidency of the United States has damaged the politics of that country, possibly permanently. ${ }^{24}$ His methods are likely to have diminished the power and

22 The Superdiversity Institute, established by lawyer Mai Chen, is a multidisciplinary Institute specialising in analysing law, policy and business implications of New Zealand's superdiversity and superdiversity globally.

23 Ko Tō Tãtou Käinga Tēnei: Royal Commission of Inquiry into the Terrorist Attack on Christchurch Masjidain on 15 March 2019 (Department of Internal Affairs, December 2020) Volume 1 at 159.

24 Bob Woodward Fear: Trump in the White House (Simon \& Schuster, London, 2018); Bob Woodward Rage (Simon \& Schuster, London, 2020); and Michael Wolff Fire and Fury: Inside the Trump White House (Henry Holt \& Co, New York 2018). The tendencies that found their expression in the Trump administration have been building in the United States for some years: see Thomas Frank What's the Matter with America? - The Resistible Rise of the American Right (Secker \&Warburg, London, 2004); and Ezra Klein Why We're Polarized (Profile Books, London, 2020). Earlier developments are also clear from Volume 1 of former President Obama's recent memoir A Promised Land (Viking, New York, 2020) at 403-407; Jill Lepore These Truths: A History of the United States (W W Norton \& Co, New York, 2018): Chapter 16 of this book "America Disrupted" gives a chilling account of the forces that culminated in the election and presidency of 
prestige of the United States in the eye of many nations. The absence of leadership on such critical issues as Covid-19 has been breathtaking. The degradation of governmental institutions that has occurred is distressing. The trends towards racism and authoritarianism are a cause for concern. A flurry of books have been published on American extremism. ${ }^{25}$ The erosion of the rule of law and the politicization of the judiciary have been damaging and the tendency has been going on for some years. $^{26}$

The degree of polarisation and the inability to compromise do not bode well despite the relief provided by the electoral victory of President Joseph Biden. The level of support secured by Trump will remain a brake on a return to orthodoxy and will test the methods by which government is conducted in the United States. It is sad that democracy has become a partisan issue - it is as if the country has split into two camps that believe different versions of reality. The United States has endured democratic breakdowns before and has overcome them. It can do so again.

Some believe Trump behaved as if he was imbued with the divine right of kings, which the American Revolution of 1776 was intended to stop. ${ }^{27}$ Trump's Attorney-General took an extremely generous and unduly wide view that everything the President did was constitutional. ${ }^{28}$ No President in American history has behaved in the way Trump has. His lies are legion. ${ }^{29}$ Indeed, he was himself the origin of much of the "fake news" about which he fulminated. He continued to lie after the polls closed. Bigotry, narcissism, deceit and divisiveness, contempt for women and civil rights are the

Donald Trump at 718-781; and Timothy Snyder On Tyranny: Twenty Lessons from the Twentieth Century (The Bodley Head, London, 2017).

25 "Fear and loathing: Assessing the threat from America's far right" The Economist (London, 12 December 2020) at 75; and Francis Fukuyama "Liberalism and its Discontents: The Challenges from the Left and the Right" American Purpose (online ed, 5 October 2020) <www.americanpurpose.com>.

26 Steven M Teles The Rise of the Conservative Legal Movement: The Battle for Control of the Law (Princeton University Press, Princeton, 2008). Despite the politicisation of judicial appointments, it is encouraging to note that this did not result in the numerous Republican appointed judges who considered Trump's challenges to the 2020 election results misapplying the electoral law.

27 Much of what is said here comes from the author's reading of The New York Times and The Washington Post to which he has online subscriptions. Correspondence with law professors in the United States has also been very helpful. To provide a citation for every point seems unnecessary since most of the points can be derived from the internet. The author has lived for more than ten years in the United States at various times and in various locations.

28 Tom Hamburger "How William Barr, now serving as a powerful ally for Trump, has championed presidential powers" The Washington Post (online ed, Washington DC, 17 May 2019) <www.washingtonpost.com>.

29 Glenn Kessler "Trump made 30,573 false or misleading claims as president. Nearly half came in his final year" The Washington Post (online ed, Washington DC, 24 January 2021)<www.washingtonpost.com>. 
charges most frequently levelled against him. ${ }^{30}$ White supremacy was encouraged again in America, notably with the "Unite the Right" rally in Charlottesville in 2017, 152 years after the end of the civil war that stopped slavery, and long after the Civil Rights Act of 1964 and the Voting Rights Act of 1965 - great reformist pieces of legislation — were enacted by Congress. It looked as though efforts may be made to return to the discrimination reimposed in the south after reconstruction.

A tendency to encourage belief among his supporters in conspiracy theories may turn out to be one of Trump's most enduring legacies. Trump persisted in asserting contrary to all the evidence that he won the 2020 election and deliberately stirred up his political base to support these unverified assertions. More than 60 lawsuits were dismissed in a variety of state and federal courts. The Supreme Court of the United States refused to intervene in cases involving the critical issue to Trump: the lack of restrictions on voting by mail. ${ }^{31}$ The suspicion was that he set out in advance of the election to consciously discredit the electoral process especially voting by mail brought on by Covid-19, in the hope he could challenge the results later and thus remain in power.

These efforts culminated in the disgraceful attempts the President made on 6 January 2021 by organizing a rally in Washington DC and urging his supporters to march upon the Capitol Building, where the Senate and the House were then considering the certification of the election results from the Electoral College. ${ }^{32}$

The mob stormed the Capitol and broke in. Proceedings were suspended. People died. And order was not restored for several hours. When business resumed the results were certified and Vice President Pence, who was presiding in the Senate, refused to heed requests from Trump to overturn the declared results. This led to threats to impeach Trump for the second time in his administration or to deploy the 25th Amendment of the Constitution to suspend him from office on the ground that what he had done demonstrated that he was "unable to discharge the powers and duties of his office." 33 The President was widely accused of inciting a riot and insurrection. While the attempt to involve the 25th amendment was not agreed to by Vice-President Pence and therefore could not proceed, the

30 The Editors of the New Yorker "The talk of the Town" The New Yorker (5 October 2020) at 10-11 and 1116.

31 American Bar Association <www.americanbar.org > . This is the most helpful source of the disposition of the cases that reached the Supreme Court. No attempt will be made to cite the many decisions of other state and federal courts.

32 Philip Rucjer and Carol D Leonnig "'I Alone Can Fix It' book excerpt: The inside story of Trump's definance and inaction on Jan 6" The Washington Post (online ed, 15 July 2021) <www.washingtonpost.com>; see also Luke Mogelson "The Storm: In the weeks before the assault on the Capitol, the Presdent and his supporters kept stoking paranoia and rage" The New Yorker (United States, 25 January 2021) at 33-53.

33 The Editors of the New York Times "Trump muted and isolated, faces the threat of Impeachment next week" New York Times (online ed, 9 January 2020) <www.nytimes.com >. 
House of Representatives voted on 13 January 2021 to impeach the President for the second time. ${ }^{34}$ As a result, the National Guard was called out, substantial efforts were made to stop another mob invasion, and similar steps were taken to protect state legislatures and official buildings. Big deployments of trained military ensured a peaceful transition of power on 20 January 2021 and a dampener on right wing extremism. The inauguration ceremony signalled a return to the normal conventions and administrative practices of American democracy that were upended by President Trump. The message called for national unity and a commitment to democracy with a recognition of its fragility. ${ }^{35}$

It later emerged that behind-the-scenes groups had been combining to take steps to protect the election through a highly organised voter protection programme. They were well funded and their extensive efforts in combatting the challenges to the election results were effective. ${ }^{36}$ The process of impeachment in the United State Constitution is based on the British practice that was common before American independence, but which later fell into disuse in Britain for good reason. ${ }^{37}$ As an instrument of accountability, the mix of political advantage and legal principle is unmanageable. After a trial in the Senate, Trump escaped impeachment by a vote of 57 to 43 , thus falling short of the two-third's majority required for conviction. Seven Republican senators voted for conviction.

The notion that a prime instrument of government communication should be tweets directly from the President seems not only novel but also dangerous. Many of the social media platforms banned him from access after his actions on 6 January, these included Facebook, Twitter, YouTube and a number of other digital platforms. ${ }^{38}$ But for most of his presidency, Trump has used social media to attack people, to provide false information and encourage conspiracy theories. The existence of these digital platforms and their effects upon democratic politics is an issue raised later in this article.

The performance of the United States on Covid-19 has not protected its citizens adequately. ${ }^{39}$ For the President to deny the science, attack his advisers and encourage people to attend his rallies without wearing masks was irresponsible. Nowhere in the world has this global pandemic been worse than

34 The Editors of the New York Times "Trump Impeachment" The New York Times (online ed) $<$ www.nytimes.com>.

35 Peter Baker "Biden Inaugurated as the $46^{\text {th }}$ President Amid a Cascade of Crises" New York Times (online ed, 20 January 2021) <www.nytimes.com>.

36 Molly Ball "The Secret History of the Shadow Campaign That Saved the 2020 Election" Time Magazine (online ed, 4 February 2021) $<$ https//time.com $>$.

37 See for example Miranda Bryant "Getting medieval: impeachment's roots go back to 14th-century England" The Guardian (online ed, 3 October 2019) <www.theguardian.com>.

38 David Alba, Elle Koese and Jacob Silver "What happened when Trump was banned on social media" New York Times (online ed, 7 June 2021) <www.nytimes.com>.

39 Lawrence Wright "The Plague Year: The mistakes and the struggles behind America's coronavirus tragedy" The New Yorker (United States, January 4 2021) at 22-59. 
the United States, clearly due to a failure of federal and state government policy and leadership. By 23 February 2021 there had been 500,000 Covid-19 deaths in the United States, exceeding the combined number of Americans killed in in the World War I, World War II and the Vietnam War. ${ }^{40}$ Trump also denied the science on climate change and has undone many environmental protections and left the Paris Agreement. He was also an advocate of the American gun culture that increases the risk of injury and death to its citizens.

Trump conducted an unsavoury government in which he has combined the power of the Presidency with his personal businesses and did not separate the two. He refused to make his tax returns publicly available as is the custom. It seems after investigations by the New York Times that this is because, as wealthy as he says he is, he has paid little tax. ${ }^{41}$ More than a few of Trump's enablers and assistants have been indicted and a number imprisoned. The number of his appointees the President fired before and after the election was extraordinary.

Trump showed a preference for authoritarian leaders like Russian President Vladimir Putin and showed scant regard for the security arrangements of Europe that the United States established with NATO and the Marshall Plan after World War II. His trade policies have damaged the World Trade Organisation by refusal to appoint appellate judges thereby disabling the rules-based system. The foreign policy of the United States has become incoherent. International treaties, cooperation and the rules-based system of international law were not promoted, and the United States withdrew from a number. ${ }^{42}$ The attack waged on the International Criminal Court by the Trump administration, including the imposition of sanctions on some people associated with the Court, was an attack on the rule of the law. ${ }^{43}$

Trump announced he would make America great again, but many have concluded Trump has reduced and damaged its international standing. How and when governance may recover will depend on the future. The degree of political polarisation remains high. The Black Lives Matter demonstrations and the reaction to them signals the need for significant reform of policing in the

40 Christine Morales and Eileen Sullivan "Biden and Harris honor 500,000 Americans Lost During Pandemic" New York Times (online ed, 22 February 2021) <www.nytimes.com>.

41 "President Trump's Taxes: A Reader's Guide" New York Times (online ed, 31 October 2010) $<$ www.nytimes.com>.

42 Jessica T Matthews "Losing No Time" The New York Review of Books (New York, 27 May 2021) at 10 reported that President Biden has rejoined a number of international organisations and agreements Trump had walked away from: the Paris Climate Accord, the United Nations Human Rights Council, the World Health Organisation the New Start Arms Control Treaty and withdrew from the Trans-Pacific Partnership Agreement (TPP). Biden has also made efforts to repair alliances and open negotiations with Iran on nuclear issues.

43 John Bellinger III "The Trump Administration's Approach to International Law and Courts: Are We Seeing a Turn for the Worse?" (2019) 51 Case Western Reserve Journal of International Law 7. Bellinger is a former Legal Adviser to the State Department under President George W Bush. 
United States. Trump's failure to address important policy issues in any systematic way was distressing. How far the incoming President Biden will be able to effectively address these issues will eventually emerge. The run-off election in the State of Georgia for two Senate seats in January 2021, both won by the Democratic Party, will ease his capacity to pass legislation and reduce the level of legislative gridlock.

The Republican Party has gone along with most of Trump's methods in defiance of its historic principles. One big Republican effort has been to try to prevent people from voting by erecting barriers to suppress the vote and then not count it. ${ }^{44}$ Trump's assertions on postal voting lack any factual basis despite their constant repetition. Constant repetition of big lies does not make them the truth, but it does sow the seeds of mistrust in the minds of many people. The facts are that the election was not close - Biden won the popular vote by more than 7 million and secured a 306-232 majority in the Electoral College. ${ }^{45}$ What the Senate under the then majority Leader Senator Mitch McConnell achieved for the Republicans under Trump were numerous conservative judicial appointments and tax cuts, especially for those who are well off.

The most serious consequences of the Trump presidency from the point of view of a democratic future lies in his use of rhetoric to inflame a mob by repeating lies over and over again. Since he occupied the highest office in the land, many people believed him. The effort to undermine democracy by storming the Capitol has caused many to turn upon Trump and denounce him. Ten Republican members of the House of Representatives voted for his impeachment. While there has been an atmosphere of authoritarianism from the beginning of the Trump administration, it developed into a serious attempt to change the result of the election and conduct, something in the nature of a coup d'état based on conspiracy theories. The idea was that the government of the United States lacked legitimacy. This tendency will lead to something approaching fascism if it prevails. A distinguished American historian has written: "Post truth is pre-fascism, and Trump has been our post-truth president." 46 Without agreement about basic facts, citizens cannot form a civil society or maintain vital institutions. The development also illustrates how over time an atmosphere can be created that will allow democratic practices and procedures to be discredited and taken away.

In the other main English-speaking democracy, the United Kingdom, things are not much better. Managing the crisis brought about by Covid-19 and completing the steps to leave the European Union

44 Spencer Bokat Lindell "The Voting Suppression tipping Point" New York Times (online ed, 29 October 2020) $<$ www.nytimes.com>.

45 James M Lindsay "The 2020 Election by the Numbers" (15 December 2020) Council on Foreign Relations $<$ www.cfr.org $>$.

46 Timothy Snyder "The American Abyss: A historian of fascism and political atrocity on Trump, the mob and what comes next" New York Times (online ed, 9 January 2021) <www.nytimes.com>; and see also Luke Mogelson "We go where they go - Antifascist activists fight their enemies online-and in the streets" The New Yorker (November 2, 2020). 
has been disruptive, damaging to the economy and the morale of people. The United Kingdom has, since the carrying of the Brexit referendum, been in a long-drawn-out crisis of governance. The scandalous use of big data by Cambridge Analytica in the Brexit referendum campaign is dealt with in section X. It has involved two general elections, three Prime Ministers, two journeys to the Supreme Court of the United Kingdom, and two defeats in Parliament for the government. ${ }^{47}$

How the future of the United Kingdom will develop, and whether it will remain as the United Kingdom, must be regarded as open questions. ${ }^{48}$ The Johnson government is attempting to curb the powers of the rather new Supreme Court and reduce accountability by throttling back on judicial review. ${ }^{49}$ These tendencies seem clearly aimed at reducing the rather meagre system of checks and balances against a strong executive that exists in the United Kingdom, one characteristic the New Zealand political culture shares with the United Kingdom. Some have argued the decline of politics in the United Kingdom has led to the courts offering less respect for the political branches of government than in the past, a difficult thesis to sustain in the political meltdowns that have been occurring there. ${ }^{50}$

\section{THE STATE}

These recent events in the Anglosphere suggest that it is necessary to consider what comprises a "State". To understand the elements of what comprises a state is a bedrock idea that is easy to assume but which needs to be analysed. Understanding the configuration of state needs greater attention, it is suggested in the new global condition that has emerged. The word "state" derives from the Latin word "status". It is not simple to define what a "sovereign state" might be. Three clearly agreed features do exist. They are that the state must have territory, people, and a government. Beyond that, the issue of definition becomes soggy. There is no requirement for a state to have any minimum geographic area,

$47 \quad R$ (Miller and Another) $v$ Secretary of State for Exiting the European Union [2017] UKSC 5. Here the Court held by a majority that an invocation of art 50 of the Treaty on European Union would remove rights enacted through primary legislation, and therefore may not be done by royal prerogative without enabling primary legislation; and $R$ (on the application of Miller) $v$ The Prime Minister [2019] UKSC 41. In the second case, eleven judges unanimously held the use of the prerogative power of prorogation is justiciable. The Prime Minister's advice to the Queen to prorogue Parliament, and the resulting Order in Council, were unlawful because they had "the effect of frustrating or preventing, without reasonable justification, the ability of Parliament to carry out its constitutional functions as a legislature and as the body responsible for the supervision of the executive" (see [50]). The order was void, and Parliament was not legally prorogued. These developments revive thoughts of what Lord Hailsham called in the 1980s "elective dictatorship". See Lord Hailsham The Dilemma of Democracy: Diagnosis and Prescription (Collins, London, 1978) at 9-11.

48 Neal Ascherson "Bye Bye Britain" London Review of Books (24 September 2020) at 37.

49 Nicholas Reed Langen "Reforming the Supreme Court" (1 December 2020) UK Constitutional Law Association $<$ https://ukconstitutionallaw.org $>$. Not only are there active proposal to reform the Supreme Court by reducing its importance and its composition but also there is on foot a review of the powers of judicial review in administrative law.

50 Jonathan Sumption Trials of the State: Law and the Decline of Politics (Profile, London, 2019). 
neither any particular number of people nor any particular form of government. There is no stipulation as to what resources are required. Yet, in the international system, massive states and tiny ones exist together in a condition of sovereign equality, at least in theory if not in reality. A state is a political organisation that forms the foundation for government. The state has legal personality, and that concept needs to be introduced. Some exposure to the controversial debates about the acquisition of sovereignty over New Zealand by the British and how that came about would be helpful in the public law course because of the issues relating to colonialism. ${ }^{51}$

State territory, including the airspace above the land and the territorial seas, the people and the government make up the physical and social base for the state. The state has legal competence over its territory and the people within it as a general rule. ${ }^{52}$ This legal competence is commonly described as sovereignty. It brings with it the legitimacy of the use of force by the state to maintain order and defend its territory against invaders.

The state is also an organised political community. People are political. As Aristotle observed: "man is by nature a political animal intended to live in a polis." ${ }^{53}$ They live together in political and social communities. It is part of their biology. They talk with one another. They have views on topics that concern them. They will speak out against things they do not like. They are interested in decisions and rules that affect them, some more than others. People are constantly on their phones messaging their friends, telling them what they think.

The social nature of humans was demonstrated clearly when they were deprived of social contact to a substantial degree by lockdowns in the Covid-19 pandemic. Social media is awash with what people think and what they want to happen. As deluded and off the wall as some of their views may be, everyone is entitled to freedom of speech and their own opinions.

A political community can be a village, a town, city, a province or a country. It can be an iwi or hapū. It can be an association formed for a particular purpose; for example, to look after the interests of teachers or farmers. In some ways, the state can be looked at as association of associations. Political

51 J Rutherford The Treaty of Waitangi and the Acquisition of British Sovereignty in New Zealand, 1840 (Auckland University College, Auckland, 1949). The issues in relation to the South Island are far from clear. The establishment of British rule is dealt with by Philip Joseph in Philip Joseph Joseph on Constitutional and Administrative Law (5th ed, Thomson Reuteurs, Wellington, 2021) at 41-49.

52 James Crawford The Creation of States in International Law (2nd ed, Oxford University Press, Oxford, 2007). It is interesting to trace the references in this respect to New Zealand in the Index to Crawford. See also James Crawford Brownlie's Principles of Public International Law (8th ed, Oxford University Press, Oxford, 2012) at 204; Malcolm N Shaw International Law (7th ed, Cambridge University Press, Cambridge, 2014) at 352358; and Alberto Costi (ed) Public International Law: A New Zealand Perspective (LexisNexis NZ, Wellington, 2020) at 3.3 .

53 Sir Ernest Barker The Politics of Aristotle (Oxford University Press, Oxford, 1957) at 6. The word "polis" in the Greek is not quite the same thing as a "state" in modern usage but refers the type of urban communities that existed around the Mediterranean at the time Aristotle wrote. 
activity takes place at many levels, in many ways. It concerns a multitude of issues. Public concern about the conduct of public affairs generates discussion and conversation. A majority may have one view, a minority another. The disagreements may become divisive. The adjustment of these differences of view in order to arrive at binding decisions is the challenge of democratic government.

People worry about issues: whether they have enough money to live adequately, the quality of schools for their children, the availability of housing at reasonable cost and access to good medical treatment. People also want to live in a safe and clean environment. These issues concern everyone. To satisfy many of these concerns are seen to be the responsibility of the government in contemporary New Zealand. In broad terms what people want is a fair go, safety and security for their families, the availability of jobs that are properly paid, and protection against disasters, such as earthquakes and pandemics.

People are also concerned with local issues: roading, transport, rubbish collection, water supply and sewage disposal. All these matters are the responsibility of local governments, which are in many ways closer to people than central government and have the opportunity to be more responsive. Public law courses should cover local government, a legally complex field in New Zealand that shows signs of dysfunction and its future is now subject to a comprehensive independent review. ${ }^{54}$

\section{INTERNATIONAL LAW}

This segment posits that international law is an important topic in any public law discourse, particularly in a nation that finds itself in the circumstances of New Zealand. The state tells us where public law begins. And it suggests that what comes first must be international law. How states regulate their relations with one another remains a vitally important subject for our future despite the retreat from international cooperation that has occurred in recent times. New Zealand is a small country of five million people remote from other countries and separated by vast areas of ocean. It is also a country that relies heavily on international trade for its livelihood. With a vast coastline, it is not an easy place to defend in the case of hostilities. As a result of these and other factors, a rules-based system of international law and treaty arrangements rank as issues of critical importance. ${ }^{55}$

New Zealand is a country impelled by its circumstances to be internationalist in outlook and active in pursuit of activities that can benefit the country through collective international action. Part I of Chancellor Kent's celebrated Commentaries on American Law began with the law of nations. ${ }^{56}$ First published in 1823 , less than 50 years after the War of Independence, it was written after his retirement

54 Department of Internal Affairs Terms of Reference: Ministerial review into the Future for Local Government (2021).

55 Clark Packard "Trump's real trade war is being waged on the WTO" Foreign Policy (online ed, 9 January 2020) <www.foreignpolicy.com>.

$56 \mathrm{O}$ W Holmes Jr (ed) and James Kent Commentaries on American Law (12th ed, FB Rothman, Littleton (Colo), 1989). 
from judicial office when appointed as Professor of Law at Columbia. Despite the contemporary retreat from international treaty making and cooperation, stimulated by both the emergence of authoritarian nationalism and the Covid-19 pandemic, there exists a strong case for emphasising the Charter of the United Nations and a taste of customary international law, which is part of New Zealand domestic law. This could be done with three interesting environmental cases. ${ }^{57}$

It may also be prudent to introduce such matters such as international trade, international aviation and international communication that are governed by international conventions to which New Zealand adheres. The importance of international organisations to New Zealand should be stressed. And the reach of war crimes and international humanitarian law could be introduced given the events that occurred in Afghanistan between 2006 and 2016 and have been disclosed in Australia. ${ }^{58}$ An inquiry into the conduct of New Zealand soldiers in Afghanistan found no misconduct of the type discovered by the Australian inquiry. ${ }^{59}$ Nevertheless, the increasing tendency of individuals to be made subject to the reach of international law, not just state law needs to be more widely understood. Like domestic public law, international law should be sensitive to issues "related to democracy, representativeness, accountability and the staples of political theory."60 The manner in which the Covid-19 pandemic and populism may handicap international law is well set out by Professor Campbell McLachlan in a recent paper. ${ }^{61}$

It logically follows from the existence of the state that increased attention to international law is necessary for New Zealand public lawyers. New Zealand is a state and recognised as such by other nations.

\section{MĀORI, THE TREATY, HISTORY AND COLONISATION}

In this segment of the article the focus moves to historic and unfinished public law business within New Zealand, particularly the continuing conseqences of colonialism. Addressing these issues properly should strengthen New Zealand democracy and assist citizens' understanding. Public law in Aotearoa New Zealand 181 years after the assertion by the British Government of sovereignty over these islands tends still to be heavily influenced by English law and English legal approaches. It

57 Corfu Channel (United Kingdom of Great Britain and Northern Ireland v Albania) (Merits) [1949] ICJ Rep 4; Trail Smelter (United States v Canada) (1938 and 1941) 3 R Int'l Arb Awards 1905; and Lake Lanoux Arbitration (France v Spain) (1957) 12 R Int'l Arb Awards 281 at 315-316.

58 Inspector-General of The Australian Defence Force Questions of Unlawful Conduct concerning the Special Operations Task Force in Afghanistan (Inspector-General of the Australian Defence Force, Occasional Report, 10 November 2020) [Afghanistan Inquiry].

59 Report of the Government Inquiry into Operation Burnham (Department of Internal Affairs, July 2020).

60 Jan Klabbers "The Cheshire Cat that is International Law" (2020) 31 EJIL 31 at 269.

61 Campbell McLachlan Populism, the Pandemic and Prospects for International Law (KFG Working Papers Series, No 45, October 2020). 
contains within it tinges of colonialism still. This despite the fact that New Zealand is one of the world's oldest democracies having achieved a high degree of self-government from 1857 onwards. ${ }^{62}$ Since becoming a signatory to the Treaty of Versailles and joining the League of Nations after World War I, New Zealand had enjoyed international capacity. It has had complete power over the instruments of its own governance since 1947 with the passage of the Statute of Westminster Adoption Act, or at the latest with the passage of the Constitution Act $1986 .{ }^{63}$

New Zealand clung proudly to the British Empire more gratefully than other Dominions and for understandable reasons among which defence and the need for trade were fundamental drivers. ${ }^{64}$ Our system of government is broadly based on the Westminster system and while we have innovated with changes, we do not pause often to examine the fundamentals. We have assumed that our system of government is secure and there is little need to consider the foundations upon which it based.

One can be pardoned for wondering why we have not done better to reflect our own indigenous cultures, customs and values within our public law system to a greater degree in modern times. ${ }^{65}$ While sweeping away tikanga was a predictable result of the activities of the settler governments, greater recognition of tikanga Māori could reasonably have been expected by now. ${ }^{66}$ We have been sidling around the Treaty of Waitangi since 1975 without grasping the nettle and taking some real

62 A H McLintock Crown Colony Government in New Zealand (Government Printer, Wellington, 1958).

63 Section 28 caused the eighteen remaining provisions of the New Zealand Constitution Act 1852 (UK) to cease to have effect in New Zealand and the statute itself was repealed in London in 1989.

64 The richness and fluctuating fortunes of New Zealand's history is well captured in: James Belich Making Peoples: A History of New Zealanders from Polynesia Settlement to the End of the Nineteenth Century (Allen Lane the Penguin Press, Auckland, 1996); and James Belich Paradise Reforged: a History of New Zealanders from the 1880s to the year 2000 (Allen Lane Penguin Press, Auckland, 2001). The story of Māori is best set out in Athol Anderson, Judith Binney and Aroha Harris Tangata Whenua:An Illustrated History (Bridget Williams Books, Wellington, 2014); and Mark Hickford and Carwyn Jones Indigenous Peoples and the State: International Perspectives on the Treaty of Waitangi (Routledge, London, 2019).

65 Matthew S R Palmer The Treaty of Waitangi in New Zealand's Law and Constitution (Victoria University Press, Wellington, 2011); Carwyn Jones New Treaty New Tradition: Reconciling New Zealand and Māori Law (Victoria University Press, Wellington, 2011); Rachel Bell and others (eds) The Treaty on the Ground:Where we are headed, and why it matters (Massey University Press, Auckland, 2017); and John McCrone "Decolonising NZ's Lawyers" The Dominion Post (New Zealand, 9 January 2021) at B4.

66 It is heartening that real efforts are now being made to rectify these defects in New Zealand legal education: Jacinta Ruru, Khylee Quince and Carwyn Jones Strengthening the Ability for Māori Law to Become a Firm Foundation Component of a Legal Education in Aotearoa New Zealand (Michael and Suzanne Borrin Foundation, Issues Paper, 2020). It is understood that real efforts are now being made to engage the New Zealand Council for Legal Education with these issues. It needs to be understood that tikanga Māori, like the common law, changes with time. What was tikanga in 1830 may not be tikanga in 2021. An interesting recent book illustrates the difficulties of encounters with tikanga in initial Māori contact with pākehā: Trevor Bentley Transgressing Tikanga: Captured by Māori-First-Hand Accounts 1816 to 1884 (Potton and Burton, Nelson, 2021). 
action to what the Treaty means for contemporary New Zealand. After all, the Treaty was the work of two parties, the British Colonial Office and Māori. British authorities were reluctant to annex New Zealand. A number of pressures were on the British to annex New Zealand, a growing number of sometime lawless European settlers in the north, the prospect of French colonisation and importantly, the agitation of the New Zealand Company that arrived before Hobson reached New Zealand. The Company started planning the Port Nicholson settlement and purchasing land before the Treaty. ${ }^{67}$ And the British authorities did not proceed until they had the consent of Māori. They did not want to subject Māori to exploitation or land jobbing and arguably wanted to secure their customs and way of life. ${ }^{68}$ Māori agreed to the Treaty but to what did they actually consent? It was not what the British thought they were getting. The Chiefs could have had no idea of the upheavals that lay ahead of them. They were under the clear impression that chiefly authority would not be greatly disturbed. The Māori text of the treaty and the oral assurances the Chiefs had received made that a reasonable conclusion. ${ }^{69}$

The expectations of Māori rapidly evaporated when Crown-Colony Government came to an end, culminating in the effective repudiation of the careful decision in $R v$ Symonds by the Wi Parata $v$ the Bishop of Wellington and the Attorney-General (Wi Parata) decision in $1877 .{ }^{70}$ Further, the Treaty of Waitangi was dismissed as "a simple nullity". No body politics existed capable of making cession of sovereignty, nor could the thing itself exist." The difference in the two language versions of the Treaty left Māori with the justifiable belief they had agreed to one thing only to see another appear in their real world.

The troubled early history of Aotearoa New Zealand clearly establishes that colonialism had a profound and lasting effect upon the lives of the people who lived here when the pākehā arrived. Māori were by far the dominant group in 1840. The arrival of new British immigrants by the ship load over a period of twenty years led to pākehā dominance. The new settlers wanted land. By the end of the New Zealand Wars, it was clear the settler governments, who now had the power backed by

67 Claudia Orange An Illustrated History of the Treaty of Waitangi (Bridget Williams Books, Wellington 2004) at 16-24; and Phillip Temple $A$ Sort of Conscience: The Wakefields (Auckland University Press, Auckland, 2002) at $242-266$.

68 For a nuanced historical analysis of the forces at play see Mark Hickford "Designing Constitutions in Britain's Mid-Nineteenth Century Empire-Indigenous Territorial Government in New Zealand and Retrieving Constitutional Histories" (2018) 46(4) Journal of Imperial and Commonwealth History at 676-706; and Mark Hickford "Colonial and Indigenous 'Laws' - the Case of Britain's Empires, C 1750-1850" in Heikki Pihlajamäki, Markus D Dubber, and Mark Godfrey (eds) The Oxford Handbook of European History (Oxford University Press, Oxford, 2018).

69 Margaret Mutu "Constitutional Intentions: The Treaty of Waitangi Texts" in Malcom Mulholland and Veronica Tawhai (eds) Weeping Waters: The Treaty of Waitangi and Constitutional Change (Huia, Wellington, 2010) at 25.

$70 R v$ Symonds (1847) NZPCC 387 (SC); and Wi Parata $v$ the Bishop of Wellington (1877) 3 NZ Jur (NS) SC 72. See also David V Williams A Simple Nullity? - the Wi Parata Case in New Law \& History (Auckland University Press, Auckland, 2013). 
military force, were intent upon imposing their ideas about how society should be organised upon Māori.

This, despite the clear aims of the Treaty of Waitangi which explicitly guaranteed to Māori a number of rights, including retention of their land and autonomy to a substantial degree. The Treaty over time developed into an instrument of colonialism, destructive of Māori mana. Māori were deprived of their land, their culture and their customs. Their way of life had been degraded and they had been stripped of their resources. The impacts upon their social, mental and emotional lives were deep. While the settlers brought with them advantageous new technologies and new opportunities for Māori economic development these were reduced by the wars.

Scholars have debated the remedies for the wrongs inflicted by colonisation. ${ }^{71}$ The methods by which this occurred over time has been described as "a brutal process and its effects on Māori have been devastating." 72 The process of colonisation is blamed for a number of social indicators for which Māori continue to suffer, including: ${ }^{73}$

- lower educational achievement because of cultural problems for Māori in a system that was foreign to their values;

- discrimination in the justice system resulting in disproportionately high rates of imprisonment;

- lack of access to health care and lower life expectancy than pākehā;

- loss of the language - the Māori Schools Act 1867 required tuition to be conducted in english; and

- urbanisation.

Debates have been held on promoting policies of decolonisation. One of the leading Māori scholars, Moana Jackson, has argued that "the ethic of restoration" may be a better way of looking at the issues than the term decolonisation. ${ }^{74}$ Whatever it is called and however it is accomplished, society cannot afford to have continuing deprivation visited upon indigenous New Zealanders.

The main point is for public lawyers to understand the contemporary relevance to early New Zealand's legal history, with an overlay of the rich repository of information and analysis contained in Waitangi Tribunal reports, that will deepen understanding. In particular, they ought to make reference to recent books on the New Zealand Wars and the land confiscations that followed. ${ }^{75}$ These

71 Bianca Elkington and others Imagining Decolonisation (Bridget Williams Books, Wellington 2020) at 22.

72 At 22.

73 At 23-39.

74 At 149

75 At 92. 
matters are fundamental to understanding modern New Zealand and the impacts of colonisation that continue. It is heartening in this regard that the Government has adopted a policy to teach New Zealand history in schools from 2022 and a draft curriculum for consultation was published in January $2021 .{ }^{76}$

Some appreciation of the features of Crown Colony Government and the background agitation by settlers that led to the Constitution Act 1852 (UK) that gave New Zealand its only written constitution has contemporary relevance. How the acquisition of responsible government in 1856 produced long standing wrongs yet to be fully addressed is also relevant to this day.

The New Zealand Wars are a massive subject that cannot be discussed in detail here. Here is a summary of the main events: ${ }^{77}$

- In 1846 the Northern war began, involving Ngā Puhi chief Hōne Heke and Te Ruki Kawiti. The felling of the flagstaff at Kororāreka upon which the British Ensign flew was their object. Heke cut it down four times. There were a number of other violent encounters with the Crown. Indeed, the town was sacked by Māori and great destruction of property and looting took place after it had been shelled by the Royal Navy. The Crown never put the flag up again after it had been repeatedly chopped down and abandoned the town and to a large degree the north.

- The incident at Wairau in 1843 is connected with the Cook Strait clashes. Nelson's settlers armed themselves, issued warrants to arrest Māori who were interfering with surveyors. But the New Zealand Company had no right to survey the land and Māori were not punished by the then Governor when 11 settlers, including Captain Arthur Wakefield, were killed. There were other clashes in the Cook Strait area in Wellington and Wanganui. There was the Battle of Boulcott's Farm in 1846 in Lower Hutt. Then Te Rauparaha was captured by Governor

76 Aotearoa New Zealand's Histories in the New Zealand Curriculum (Ministry of Education, Draft for Consultation, January 2021).

77 The literature relied on for the New Zealand wars includes Vincent O'Malley The Great War for New Zealand - Waikato 1800-2000 (Bridget Williams Books, Wellington, 2016); Vincent O'Malley The New Zealand Wars - Ngā Pakanga O Aotearoa (Bridget Williams Books, Wellington, 2019); James Belich The New Zealand Wars and the Victorian Interpretation of Racial Conflict (Auckland University Press, Auckland,1986); James Belich I Shall not Die - Titokowaru's War 1868-1869 (Bridget Williams Books, Wellington, 2010); Keith Sinclair The Origins of the Māori Wars (2nd ed, Auckland University Press, Auckland, 1974); Danny Keenan Wars Without End / Ngā Pakanga Whenua o Mua: New Zealand's Land Wars - A Mãori Perspective (Revised Edition, Penguin Random House, New Zealand, 2021). See also Ron Crosby The Forgotten Wars: Why the Musket Wars Matter Today (Oratia Books, Auckland, 2020). See also Tamihana Te Rauparaha He Pukapuka Tātaku I Ngā Mahi a Te Rauparaha Nui (Auckland University Press, Auckland, 2020). The editor's note at page 3 of this last work dealt with some uncomfortable aspects of tikanga and, quoting from evidence given to the Waitangi Tribunal, this appears:

Well, that's the traditional Māori world, what they did was to kill people, eat people, forcibly take possessions and land, undertake conquest - even though it's unpleasant, that's the traditional Māori world. 
Grey and taken to Auckland. Another attack was made on Te Rangihaeata at Pāuatahanui in 1846. Martial law was extended to Wanganui in 1846-1847.

- The Taranaki Wars of 1860-1861 and 1863-1864 began over a land purchase the New Zealand Company thought it had made of 600 acres at Waitara. The Governor backed the validity of the purchase and 400 troops marched on Waitara. Other clashes followed. British troop numbers were increased and Māori from Waikato and Ngāti Maniapoto travelled to Taranaki, and some of them fought in aid of the local Māori. The British suffered a crushing defeat at Puketākauere in June 1860.There were other engagements and ambushes and matters sputtered to end in 1864 .

- The greatest conflict in the New Zealand wars the Waikato War of 1863-1864. The Governor delivered an ultimatum to the Māori King, demanding submission to British sovereignty and warning that Māori who defied the law would find their rights under the Treaty forfeited. While preparations were made, there were delays but then the Crown and Governor Grey set out to defeat militarily the Kīngitanga. There were at least 10 significant military engagements and in some, the British were seriously defeated. Māori lost some too but never surrendered and, while defeated, they withdrew to the King country where they remained unmolested until 1885. Waikato was the pivotal war that settled that the British demanded recognition of the Crown's authority, and it became evident that power sharing with Māori was not going to happen. The British expended great resources on the Waikato war including fortified steamer gunships on the Waikato river and massive quantities of men and equipment.

- The War at Tauranga was also significant. There were two significant engagements before the celebrated events at Gate Pā on 29 April 1864. A heavy artillery barrage, including use of a 110 pound Armstrong gun, made the British believe that they had pacified the pā, only to find when they entered it their troops were cut to pieces by concealed warriors. The British had fallen into a trap. There were other engagements as well.

- The West Coast campaign of 1864-1866 occurred after the Pai Mārire, sometimes called the Hauhau, was founded by a Taranaki prophet and engaged in a number of violent acts on settlers. A number of engagements under a series of British generals took place around New Plymouth and Whanganui and up the Whanganui River.

- The East Coast Wars of 1865-1866 began with the murder of a German missionary Carl Völkner at Ōpōtiki in which he was hanged in public and distasteful acts performed on his body. Punitive expeditions were mounted, and the people involved were found, tried and executed. One of them was wrongly executed and was much later pardoned. Land confiscations followed. Other military engagements also followed - Gisborne, Wairoa and further south in Hawke's Bay. These conflicts polarised Māori because the Crown policy forced them to choose sides. Significant numbers were opposed to the Pai Mārire and many adherents were killed. 
- Tìtokowaru's War 1868-1869. This man is regarded as one of the best generals New Zealand ever produced. First he attacked a garrison near Hawera. Ten of the garrison were killed. Revenge was determined upon and 350 troops set out and they were roundly defeated and humiliated. Twenty-four of the colonial forces were killed. A further defeat followed. The situation was serious for the Government and Wanganui was threatened, but during a further attempt to engage him, the Māori simply faded away. This apparently occurred because Tìtokowaru had slept with the wife of one of his men.

- In 1881 John Bryce, the Minister for Native Affairs, mounted on a white charger, led 1,600 men into Parihaka arresting their leaders Te Whiti o Rongomai and Tohu Kākahi and also Titokowaru. Although there was no resistance, because the leaders were practitioners of the arts of passive resistance, there were multiple rapes, and the village was destroyed. The people arrested were detained without trial and imprisoned in the South Island. A special Act of Parliament had to be passed to permit such an illegal action. In 2017 the Crown made a full apology for these outrageous acts and paid compensation.

- Te Kooti had been imprisoned without trial when he surrendered to the Crown in 1865 and was sent to the Chatham Islands. About 300 Māori were sent there. He engineered an escape capturing a supply ship that called at the Chatham Islands port and he and 298 prisoners arrived near Young Nick's Head on the East Coast. Troops tried to capture them, and armed encounters began. Several attempts failed to capture Te Kooti. He made a number of attacks on his enemies and a price was put on his head by the Government. His pā in Ngātapa was attacked in 1869 by 700 men, including some Ngāti Porou. Te Kooti fled and many of those left behind were executed without trial. The hunt for Te Kooti went on for a long time but he evaded capture and was granted shelter by the Tūhoe of the Te Urewera. When Te Kooti was hunted out, he went to Tongariro district where he was engaged and defeated. He fled and kept fighting between 1870 to 1872 . He was later pardoned. He spent the final part of his life in the Bay Plenty promoting the Ringatū faith he founded.

Māori were excellent soldiers and skilled military tacticians. They won a significant number of military engagements. The Crown had 18,000 imperial and local troops under arms at the time of the Waikato war. Even with their superior technology and armaments, the Crown had great difficulty in prevailing and essentially gave up. Imperial forces were withdrawn between 1867-1869. The British government had had enough. The colonial government thereafter shouldered the whole burden, and the wars were expensive. Māori were never finally conquered in the conventional sense of how that term was used in Europe.

In fact, there were many places within the North Island where the Queen's authority did not run. Māori in remote areas lived relatively undisturbed by the new governance arrangements. In the King Country, or Rohe Pōtae, this situation continued until after the main trunk railway was constructed and opened in 1885. The King movement had retreated to the King Country after the Waikato war and they were not pursued. Long negotiations were held before the railway could be built through the 
King Country. ${ }^{78}$ Although the figures are likely to be inaccurate, it is thought more than 3,000 perished in the New Zealand Wars, the majority of them Māori. Accurate numbers are not available. ${ }^{79}$

Massive land confiscations against Māori (known as Raupatu in te reo) were made by legislation during and after the New Zealand Wars. The New Zealand Settlements Act 1863 followed from the powers given to the settler governments to make law, by the passage of the New Zealand Constitution Act 1852 in London and the acquisition of responsible government soon after. The preamble to the 1863 Act recites that there had been "insurrections amongst evil-disposed persons of the Native race." 80 They were engaged, it said, in open rebellion against Her Majesty's authority. The Act gave power for the Governor to declare districts within which a tribe or any considerable number of it was engaged in rebellion to define the areas. ${ }^{81}$

It was made lawful for the Governor in Council to set aside such districts for settlements for colonisation. Confiscations took place in Waikato, the Bay of Plenty, Taranaki, South Auckland, Hauraki, Te Urewera, Hawkes Bay the East Coast. Some tribes fought on the side of the Government in some of the New Zealand Wars. Yet some of them suffered confiscation as well. The effects were traumatic upon Māori. Some of the land was returned shortly after confiscation and some Māori were able to benefit from this action. Nevertheless, the effects were serious. The best analysis available states that 3,676,058 acres of Māori land were confiscated or ceded to the Crown, the two largest areas being the Waikato and Taranaki. The wars and their aftermath condemned many Māori in the North Island to a life of poverty. Māori never received what they thought the Treaty of Waitangi had given them. ${ }^{82}$

Many injustices were inflicted upon Māori. In modern times, some redress for wrongs has been made in the form of negotiated Treaty of Waitangi Deeds of Settlement between the Crown and Māori. The substance of the relief agreed in each case is enacted by Parliament. These processes have yielded more than 50 settlements by 2014 and they are still being carried out. Under these settlements land and other assets were handed over to Māori as well as capital. A deadline of 2020 for the completion of the historical settlements was established but that deadline was not met, and a number of claims are still being dealt with. Many deadlines have been set and missed over the years.

78 Michael Belgrave Dancing with the King:The Rise and Fall of the King Country, 1864-1885 (Auckland University Press, Auckland, 2017).

79 See Ministry for Culture and Heritage "New Zealand's 19th-century wars: End of the New Zealand Wars" (30 October 2019) New Zealand History <https://nzhistory.govt.nz>.

80 New Zealand Settlements Act 1863, preamble.

81 Section II.

82 Richard Boast Buying the Land, Selling the Land: Governments and Māori Land in the North Island, 18651921 (Victoria University Press, Wellington, 2008) is the most authoritative account of the land policies of the settler governments. 
There were other relevant developments in the nineteenth century. In 1862 a Native Lands Act was passed and another in 1865. These established the Native Land Court, now the Māori Land Court. The object was apparently to cure the problems with collective ownership of land by Māori by full individualisation of title. Customary title could be extinguished and replaced with a Crown grant. The old pre-emptive right of the Crown system introduced in 1840 was abolished. Māori were free to sell their land and indeed to buy it. It became Māori freehold title. Large quantities of land began to pass through the Court. There were problems in sorting out and finding the tribal owners and doing surveys. All this was costly. Further, the Court had to apply native customary law in a system that did not recognise individual tenure. The new system was effective in breaking up the tenure of land by tribes. But there were elements in it that protected Māori interests. Some historians have condemned the whole process and efforts are still being made to improve the system. What emerged was a hybrid that gave the owners individual geographically undefined shares in the land and this allowed Crown purchasers to secure sales from vulnerable owners without hapū consent. ${ }^{83}$

In 1867 the law was changed to allow Māori to have parliamentary representation. Four seats were added and all Māori males over 21 could vote, a privilege not then available to all pākehā males, who were subject to a property qualification. Māori who had individual freehold property could also vote in European electorates, a right not abolished until 1893. The seats became permanent and there are at present 7. These days, since 1975, Māori can periodically elect which roll to be on-the Māori roll or the general roll. ${ }^{84}$ These seats have from time to time been the subject of controversy. Interestingly enough, non-Māori males did not have a universal right to vote until 1879. And as is well known, women were given the vote in 1893 . New Zealand was the first country in the world to do so, a fact in which New Zealanders take civic pride still.

While the view expressed by the court in Wi Parata is now recognised as being based on a wrong approach to both international law and British colonial practice, it was an approach that persisted for a long period and was in line with the views of the British settlers in colonial New Zealand. It remains the law of New Zealand that the Treaty cannot be enforced in the courts unless it has been made part of the statute law of New Zealand. ${ }^{85}$ Sir Kenneth Keith in the course of a long scholarly career has written creatively on the Treaty. He suggested as long ago as 1965, given the difficulties surrounding the Treaty as part of international or domestic law, whether "the courts should not have recognised the Treaty as a domestic contract." 86 In 2020 he returned to that issue in his article "The Treaty of

83 Richard Boast, above n 82, at 93-95.

84 Electoral Act 1999, ss 76, 77, 78 and 79. For a review of the history, see "Māori and the Vote" New Zealand History (20 December 2018) <https://nzhistory.govt.nz>.

85 Hoani Te Heuheu Tukino v Aotea District Māori Land Board [1941] AC 306 (PC).

86 K J Keith "International Law and New Zealand Municipal Law" in J F Northey (ed) The AG Davis Essays in Law (Butterworths, London, 1965) 130 at 148. 
Waitangi as a 'Contract'". The impression grows in my mind that more progress can be expected from the courts on the issues and in developments in New Zealand common law. ${ }^{87}$

Notwithstanding the bad effects of a number of colonial actions, it should be appreciated that the British brought approaches to governance that were positive and enduring. The need for elections of decision-makers, limits upon the powers of government, and a commitment to the rule of law were among them. The government had to be conducted under the law and not above it. The system of parliamentary government, where decisions are debated, scrutinised and discussed, before being agreed is beneficial. A commitment to a generous amount of personal freedom, with government being kept within limits was part of the approach that led to liberal democracy. And a system of public administration that is free from corruption and bribery was well established.

\section{SOME POLITICAL PHILOSOPHY}

The inclusion of this segment rests on the idea that political philosophy informs the content of many policies that are adopted by governments. Some appreciation of the range of these considerations can provide a useful framework for thinking about the content of policy and frameworks for governance.

For centuries, political philosophers have argued about the best method for organising power within a state. ${ }^{88}$ The famous ancient Greek philosopher Plato argued for rule by the best people, selected on merit. ${ }^{89}$ In his ideal state, they were to be selected as children for their intelligence. They would be carefully educated and brought up so they would be wise, objective and personally disinterested. They would understand the virtues of wisdom, temperance, courage and justice. Thus, they would be virtuous and incorruptible rulers. At the age of 50 they would reach the vision and become part of the supreme ruling council. The purpose of the ideal state was to produce justice in a human society.

Women were eligible as well as men. These were the most meritorious people to rule. Plato called them philosopher kings. He thought brains and ability outranked inherited nobility, wealth, or land as the basis for deciding who should rule. Plato approved of the state being invested with great power and the philosopher kings made all important public decisions. Plato believed ordinary people lacked

87 K J Keith "The Treaty of Waitangi as a Contract: A Personal Journey" in Simon Mount and Max Harris (eds) The Promise of Law: Essays Marking the Retirement of Dame Sian Elias as Chief Justice of New Zealand (Lexis Nexis, Wellington, 2019).

88 The most useful general works on political philosophy I have found are George H Sabine A History of Political Theory (3rd ed, Harrap, London, 1957); Bertrand Russell History of Western Philosophy (2nd ed, Allen \& Unwin, London, 1961); and A C Grayling The History of Philosophy: Three Millennia of Thought from the West and Beyond (Penguin Viking, London, 2019).

89 Francis M Cornford (translator) The Republic of Plato (The Clarendon Press, Oxford, 1941). 
the capacity to rule effectively. This scheme could be regarded as a meritocracy, if intelligence is to be regarded as the measure of merit. Other definitions of merit may be available.

The other great Greek philosopher Aristotle, a student of Plato's, developed different views. ${ }^{90} \mathrm{He}$ was not so sure about Plato's ideal state. He thought politics should be studied as a science. It needed to be concerned with how states were actually ruled, not just with how the ideal state looked. Theory was one thing; the mechanisms by which power was exercised another. Private property was a necessity, Aristotle thought, although Plato's philosopher kings could have none nor have a family.

The ideal may not be capable of achievement in the real world. Different kinds of rule are possible. It may be preferable to live under the rule of the best laws, rather under decisions made by the most intelligent person. Long developed customs and practices should not be lightly abandoned. While the state has an ethical purpose, there may be different ways of achieving it. Aristotle was no revolutionary in the sense that Plato was. He was empirical. The power arrangements within the state are likely to reflect that kind of life people want to live. States, whatever form of government they adopt, may or may not be actually ruled to serve the general good.

The great English political philosopher Thomas Hobbes, drawing on the experience of the English civil war, thought that human nature had some bad tendencies. ${ }^{91}$ In his view peace and order, not civil war, is the most important objective. People are interested in self-preservation and they need to have confidence that other people will not disturb them. This calls for a powerful and indivisible state, invested with unlimited powers. Its job is to keep everyone safe. Competitive and ruthless qualities in human nature have to be curbed for the good of society as a whole. The state is a "leviathan" - a monster that no-one loves, but whose power is absolute. It is necessary for preserving individual peace and security. For Hobbes despotism was preferable to anarchy. The power of the leviathan could not be taken away unless it failed in its duty to keep people safe, in which case people had the right to rebel against it. That seems to suggest that the ultimate political authority resides in the consent of the people.

The consent of the people hang over two big political issues: the type of government adopted by a state, and the policy objectives to which that government is directed. The issues are intertwined, but it may be helpful to distinguish between them. Do the people who live in New Zealand consent to the existing governance arrangements? Are they content to live in a democracy? Probably. But that is not end of the debate. What type of democracy do New Zealanders want, what powers should it have, and what social purposes should it pursue?

90 Barker, above n 53.

91 Thomas Hobbes Leviathan or, The Matter, Form, and Power of A Commonwealth Ecclesisastical and Civil (Blackwell, Oxford, 1957). 
Given that various forms of government are available, do people consent to the form of government that exists? Many political philosophers have argued that there exists something in the nature of a social contract between the governors and the governed. The problem is that no such legal contract has ever existed in fact, nor can it exist. In many ways, the whole idea of a social contract between the ruler and ruled is a fiction. No such contract has ever been explicitly and consciously made. It would be unmanageable since people die and others are born; do they all have to sign up? Social contract theory is a rationalisation of the lack of consent that exists in reality.

John Locke, a defender of the 1688 revolution in Great Britain, was determined to find a theory that exploded the divine right of kings theory favoured by the Stuart Kings. ${ }^{92}$ Freedom had to be surrendered by people to a degree so as to secure the benefits of living in an ordered society, he argued. A state of nature was too chaotic. A ruler could not make war on his subjects. A government that behaves in that way that is contrary to the public good, ceases to be legitimate, Locke thought. There is a duty to overthrow illegitimate governments. Power is held on trust.

People had certain rights as asserted by Locke: the right to life, liberty and property. These rights were not to be surrendered to the state by any social contract. Instead, the system should be based on laws clearly promulgated, applied by independent judges and capable of being enforced. If there is no explicit consent from people who agree to live under a particular system of government, then there does need to be means to ensure the system can be adjusted peacefully, so that it can meet current expectations of the governed and can deal effectively with new problems that arise, as they always do.

If a state with defined and accepted boundaries exists with a population of people within it, what should its institutions and decision-makers be trying to achieve? A prime obligation, as Hobbes suggests, is to provide security: security against invasion from other countries, security of the people in their person and their property. To accomplish that, it is necessary to have a functioning criminal law to deter criminal behaviour, a police force to detect offences, and a judicial system in which to impartially try the offenders.

Jeremy Bentham's principle of utilitarianism taught that the purpose of government was to produce the greatest happiness for the greatest number of people. ${ }^{93}$ Pain and pleasure are the two elements. Happiness being pleasure and its absence pain. John Stuart Mill, although a utilitarian, also believed in liberty. People exercising their own liberty had to be careful not to damage others where

92 Peter Laslett (ed) Locke: Two Treatises of Government (Cambridge University Press, Cambridge, 1960); and Sir Ernest Barker (ed) Social Contract:Essays by Locke, Hume and Rousseau (Oxford University Press, London 1958).

93 Jeremy Bentham A Fragment on Government (Blackwell, Oxford, 1948). 
their actions affected others. Self-protection was the basis for interfering with liberty. Mill was adamant that liberty means that free expression of all opinions should be permitted. ${ }^{94}$

We are all ignorant as to what the future may bring. How to produce what may be termed a just society in difficult circumstances is not an easy goal to accomplish. Such ideas as equality of opportunity have to compete with ideas of equality of outcomes. There may be agreement these days with John Rawls' idea that the purpose of government is to create the principle that justice is fairness. ${ }^{95}$ Fairness is fine in the abstract but converting it into workable policies in the real world is elusive. Rawls proposed a scheme that travelled towards equality. Social and economic inequalities are to be dealt with so that both are for the greatest benefit of the least advantaged in the community. And such purpose is also attached to offices and positions open to all under conditions of fair equality of opportunity. ${ }^{96}$ If that is not the case, they are unjust. Another modern political philosopher, Robert Nozick contests the Rawlsian view. ${ }^{97}$ He develops a more libertarian approach that individuals have rights and that cannot be lightly interfered with. He wanted a minimalist state. His 1974 book Anarchy, State, and Utopia, shocked the philosophical world with its robust and sophisticated defence of the minimal state. The state should limit its activities to the protection of individual rights of life, liberty, property, and contract and does not support the use of state power to redistribute income, to make people moral, or to protect people from harm. One wonders how that approach would in an effort to combat a pandemic.

Machiavelli is sometimes regarded as a political philosopher and sometimes as a practical adviser about political strategy and diplomacy. He appears here as a placeholder for political management, and also the darker arts of politics, the manipulation of public opinion, and the uses of it to influence elections results as in the Cambridge Analytica literature, the preparation of propaganda, the repetition of big lies, the use of fake news and spin. Some attention also needs to be given to the literature on conspiracy theories. All these must in my view be introduced in a modern public law course.

It may be useful to outline the advice to rulers that the Renaissance diplomat from Florence, Niccolò Machiavelli, provided. His slim and most famous volume The Prince was published in $1513 .{ }^{98}$ It is a book of advice to rulers about how to get political power and how to hold on it. Some of the advice still shocks. It has given rise to the word "Machiavellian" - which means a person who

94 John Stuart Mill Utilitarianism, Liberty and Representative Government (Dent, London, 1964).

95 John Rawls A Theory of Justice (The Belknap Press of Harvard University, Cambridge, 1971).

96 At 62.

97 Robert Nozick Anarchy, State and Utopia (Blackwell, Oxford 1974).

98 Quentin Skinner and Russell Price (eds) Machiavelli:The Prince (Cambridge University Press, Cambridge, 1988); and Niccolo Machiavelli The Prince and the Discourses (Modern Library, New York, 1950). I have not quoted directly from the discourses because it is a more nuanced book than The Prince and shows Machiavelli had more scruple than depicted in The Prince. 
uses political methods that that are cunning, scheming, unscrupulous and in bad faith. Deception was one of the tools of the ruler: "And men are so naïve, and so much dominated by immediate needs, that a skilful deceiver always finds plenty of people who will let themselves by deceived." 99 Deception was a sound policy since it did not involve violence.

To understand Machiavelli's advice, some context is necessary. Italy did not then have a unified government for all Italy as it has now. It was divided into republics, monarchies, city states, and states run by the Pope, who had both political and military power in those days. Florence, then a republic, was surrounded by the Papal States, Romagna, the Duchy of Milan, and the Republic of Venice. Armed conflict occurred relatively frequently. For about 12 years, Machiavelli was the equivalent of Florence's Foreign Minister and Minister for war. In that capacity he was engaged in many negotiations and disputes with other states engaging with their rulers and advisers. His books are a distillation of advice based on his experience.

Machiavelli believed in a state with a monarchy of complete power. He thought that was the only thing capable of working in the Italy of his time. Democracy would not work. In that form of government only the mediocre will rise. And for this reason, a democracy is never governed by the most competent, but rather by those whose insignificance will not jeopardise anyone else's selfesteem. For Machiavelli, power is the pivot on which everything hinges. He who has the power is always right; the weaker is always wrong. Concealing facts was acceptable. If the concealed fact does become known, the ruler needed to have a quick and ready defence.

Machiavelli had a bleak view of human nature: people in general were fickle, hypocritical, and greedy. It was necessary for the ruler to assume that all men are evil and that they are always going to act in accordance with wickedness whenever they can. To secure power and hold on it was necessary to be ruthless. It was necessary to use force and have a good army that was loyal to the ruler. Rulers had to be centrally concerned with "war and its methods" in order to stay in power. ${ }^{100}$ Mercenaries were no good, the troops needed to be loyal. The only certain way to keep control of a city that has been independent is to destroy it.

A ruler: ${ }^{101}$

... cannot always act in ways that are considered good because, in order to maintain his power, he is often

forced to act treacherously, ruthlessly or inhumanely, and disregard the precepts of religion.

Another axiom was that if a choice had to be made by a ruler it is far safer to be feared than loved. Machiavelli teaches that the stupidity of vulgar people allows them to be deceived as to always be

99 Skinner and Price, above n 98, at 62.

100 At 52.

101 At 62. 
taken in by appaearances. The world consists chiefly of the vulgar. Machiavelli teaches also that that the stupidity of vulgar people allows them to be deceived as to always be taken in by appearances and the world consists chiefly of the vulgar. And the advice tells rulers that everyone sees what you appear to be, few really know what you are. Flexibility is also a necessity. Things change events have to be reacted to and the ruler will lose his position if he is not vigilant at all times.

Perhaps the most stunning feature of Machiavelli's advice lies in his basic indifference to the morality of the ruler's behaviour. He takes the view that the end of surviving in power justifies the use of terrible means to accomplish it: ${ }^{102}$

... men should either be caressed or crushed; because they can avenge slight injuries, but not those that are very severe. Hence, any injury done to a man must be such that there is no need to fear his revenge.

So, the ruler should never do an enemy a small injury. The prince is entitled to use cruelty and even murder if that is necessary. He can be a tyrant. A ruler had to know how to behave badly. The ruler can do evil if good will come of it. Ruling depends largely upon force and skilful statecraft. One can read Machiavelli as saying politics is an end in itself and that winning is the only thing. The ruler is the law giver, and he can by those means control both the state and society. Aspects of Machiavelli's advice can be applied to democratic politics, even in New Zealand. It is possible to read Machiavelli to the effect his prime interest was the survival of the state rather than the perpetuation of political power. That is the charitable view. What would Machiavelli have said about the serious reductions of personal liberty in New Zealand resulting from Covid-19?

Machiavelli was an ultimate realist about power. The application of his advice to modern politics is persuasive. The power issues do not change only the context. Indeed, Jonathan Powell, Prime Minister Blair's Chief of Staff, wrote a fascinating book applying Machiavelli's doctrines to the real political life he experienced working for Blair. ${ }^{103}$ The need to be ruthless, (even cruel) and to dissemble were all applied according to the book. The book shows how practical Machiavelli's advice can be in the modern context of a Westminster Parliament and Cabinet government. Such issues of access to the leader, the allocation of offices, the relationship between the politicians and the public servants and who is on top, the problems with allocating portfolios, the resistance to change, the need for courage and emotional intelligence, the disasters of dithering, how to manage crises which are constant in government, how to hang on to the big picture, how to communicate and how to spin, how to manage Cabinet, how to deal with flatterers, how to deal with enemies and avoid making more, how to deal with issues of hubris, arrogance and losing touch with the real world within the political bubble, how to deal with media moguls and the media generally without obsessing about it and how

102 At 9.

103 Jonathan Powell The New Machiavelli: How to Wield Power in the Modern World (Vintage, London, 2011). For a different perspective using management concepts see Jennifer Lees-Marshment Political Management: The Dance of Government and Politics (Routledge, Abingdon, 2021). 
to leave office are issues all run through the lens of Machiavelli, with plenty of quotation and reference to his advice. The need for a strategic approach is emphasised again and again. The factors mentioned are real political issues on how to run a government.

The philosophical arguments will continue. A re-examination of them could sharpen the appreciation of the appropriate policy settings for New Zealand. But in the practical life of government and decision-making life goes on. Policies tack, jibe and change direction. The state takes on more activities or drops some. The eternal function of politics is to provide a mechanism within which public decisions are made and carried out. Over time the preferences of the population change, and policies change with them.

\section{TYPE OF GOVERNMENT}

Democracy is not an inevitable form of government. In order to sharpen our appreciation of democracy it useful to consider the other options. For that reason, this segment of the article sets them out.

The relative merits of the various form of government are hard to judge between, because all forms of government are capable of abuse according to Aristotle. While the ideal state may be a useful touchstone, it has to yield to the conditions of actual government on the ground. Politics is the art of the possible, given the real political forces that exist. It is necessary to examine how things actually work. The form of government may be one thing, but it is necessary to see what happens. For example, both oligarchies and democracies can degenerate into tyranny. Politics is empirical, it is about what is the best achievable in the circumstances.

The main options for forms of governance available, at least in theory, are: ${ }^{104}$

- meritocracy;

- feudalism;

- dictatorship, autocracy and totalitarianism;

- oligarchy, aristocratic government, plutocracy;

- monarchy;

- theocracy;

- indigenous forms;

- democracy; and

- anarchy.

Indigenous forms have been discussed in Part VI and they are important in New Zealand. Two others, democracy and anarchy, are worth some more attention.

104 I have not footnoted this portion of the paper. The literature is too big and while I have read a number of sources the views stated are my own as to the character of the various forms of government. There is a range of different views on these issues, for example what "socialism" is. 
Voting for major decision-makers is the most salient sign of democracy. Democracies hold that governments are accountable to the people. Important laws and decisions are made by elected representatives. There are elections to determine who the decision-makers will be for a set period. People have to have attained a certain age to be able to vote (at present, 18 years in New Zealand). Every vote of a person is worth the same as every other person. Political parties can be formed and compete for votes in the elections.

Elections are regulated to ensure they are fair and free. Free speech encourages public debate. People are free to criticize the government. The government cannot suppress dissent. Freedom of assembly is an important element of democracy and independent courts to apply the rule of law. Democracy means government by a majority of the elected representatives who can be dismissed at the next election. Abraham Lincoln, a famous United States President, said in his Gettysburg Address of 1863 that "government of the people, by the people, for the people" was why the United States civil war was then being fought. In this sense, democracy is government by the people, although it is their elected representatives that make the decisions. Lincoln's statement implies the people rule and they do not do so directly. This may lead to arguments that representative democracy is not really democratic. Many different types of democracy are possible. Direct democracy is where the people vote directly on all new laws and big policies. Representative democracy is where voting results in the choice of decision-makers but the decisions themselves are made by those elected not the people directly. Liberal democracy may be understood as involving free elections with competition between political parties. There will be some separation between the different branches of government, the legislature, the executive government, and the judiciary. The rule of law and protection of human rights will be in evidence. A constitution will delineate the powers of government. One possible variety of democracy could be regarded as mob rule or its relative populism. Popular passion, prejudice and disorder may produce bad outcomes, which nevertheless reflect a segment of the popular will. This variety of democracy could be called populism.

A social democracy will have widespread access to social services such as education and health care. There is also sometimes encountered the term "totalitarian democracy" where a system in which lawfully elected representatives maintain the integrity of the state. ${ }^{105}$ Then people have the right to vote but have little or no involvement in the decision-making process of the government. Russia appears to be governed in that fashion. In 2021 there were about 70 democracies in the world, depending upon how they are analysed.

Anarchy in its purest form is where there is no government at all. There is no rule of law. There is no acceptance that an institution or person has authority over any other. Even if there is a state it has no means of social control. People do as they wish. They cannot be coerced by the government. In the absence of government there is a complete freedom for every individual. There may not even

105 J L Talmon The Origins of Totalitarian Democracy (Mercury Books, London, 1961). 
be a state, although if there is its authority is minimal. The theory is that self-government is based on voluntary institutions. There should be no hierarchy of authority.

Stealing and looting of other peoples' property could easily occur in such a system. Violence will bring power to control other individuals and the system could turn into what is called a kleptocracy, where those in charge pursue personal wealth and power using stand-over tactics. In such a system, people remain in what is sometimes called a state of nature, where life can be nasty, mean, brutish and short. There is no public order. Crime will not be controlled because it has no legal consequences. Private power can be exerted by the strong over the weak. There will be no civil peace but rather conflict, often accompanied by violence.

Anarchy, however, can also mean that people have expressly decided and consented to there being no government. They accept no hierarchies of authority. In practical terms unrest, confusion and chaos seem likely. On the other hand, a strong movement was formed in the 19th century that believed that anarchy was the best way to organize human society. A libertarian movement exists that desires much less government. This leads on to the issue as to what people want the state to do, it can be responsible for a great deal or very little.

History has witnessed versions of all these forms of government. Within each type there are large number of possible variations available, for example no two dictatorships or democracies are likely to be organized exactly the same way. It will not have escaped attention that elements of each of these forms of government can sometimes be found in another form. For example, a democracy could have a state religion, as some do. A monarchy can be a democracy, where the King does not rule.

State power can be organised in many different ways. Many forms of government are available in the world. How choices between them are made requires asking and answering some fundamental questions. We need to have some understanding of the forms of government that exist. Then comes the issue of how we do decide on the best form. That involves discussing what the obligations of the state are to its citizens. And do people have to consent to the form of government adopted? We need to begin by clarifying what a state is.

An enormous two volume study of why nations fail or succeed was published in 2014. ${ }^{106}$ Professor Fukuyama found that a successful state requires three elements. First, the state needed to be competent. That means its administration must be efficient. The authority of the state must be respected within its territory. There cannot be areas that act independently and undermine or even make war on the state. The state must enjoy a monopoly on the legitimate use of force over its territory.

106 Francis Fukuyama The Origins of Political Order From Prehuman Times to the French Revolution (Profile Books, London, 2011); and Francis Fukuyama Political Order and Political Decay: From the Industrial Revolution to the Globalization of Democracy (Farrar, Strauss and Giroux, New York, 2014). See also his interesting book Francis Fukuyama Identity: Contemporary Identity Politics and the Struggle for Recognition (Profile Books, London, 2018). 
The state must be free from corruption. That means those with money cannot bribe government officials to do things for them that others cannot secure. There are many states in the world with significant levels of corruption and cronyism. Fortunately, so far, New Zealand is not one of them. ${ }^{107}$

Second, a successful state must have a strong rule of law. Everyone must be equal before the law. Laws must be applied uniformly to the whole society. This includes the law makers themselves and those who enforce the law. The powerful are as bound by the rule of law as the humble, no-one is above it. To have a strong rule of law, the judges have to be independent of the executive government, which means Cabinet and the public service. Judges must be independent of Parliament as well. Judges must make their decisions according to law set out in Acts of Parliament and the New Zealand common law, not in accordance with political instructions.

Third, the successful state must enjoy democratic accountability, which is accountability of those in power to the people they govern. The state must be responsive to the interests of the whole society. The state needs strong institutions that will hold decision-makers to account for the decisions they made for which they are answerable. The power of the state must be controlled and used in a way that most people find acceptable. States must change and adapt if they are to avoid decay.

There exist within the world more than a few failed states. They may lack authority over all of their territory. They will have weak rule of law. Corruption is likely to be common. They are also likely to be poor. Somalia, South Sudan, Yemen, Afghanistan and Syria are 2020 examples. Obviously, failure is a relative thing; some states will fail in some policy respects but succeed in others. ${ }^{108}$

Indeed, it is an evident truth that all states produce policy blunders and mistakes quite frequently, both big and small. ${ }^{109}$ States can and do deteriorate and disintegrate over time. Leaders may resort to repression and institutions like a powerful security apparatus to stay in power. States can become fragile for a variety of reasons: economic decline, poverty, civil unrest, denial of human rights, and a sense that the rulers lack legitimacy.

\section{WHAT ARE THE AVAILABLE POLITICAL IDEOLOGIES?}

Political ideology is regarded as an essential consideration to understanding the system of government since it influences many political attitudes and beliefs among elected representatives. What they believe has implications for what is decided in Parliament and by political parties. The range of ideologies is broad, and some appreciation of its circumference is important.

107 Fukuyama Political Order and Political Delay: From the Industrial Revolution to the Globalization of Democracy, above n 106, at at 25.

108 Daron Acemoglu and James A Robinson Why Nations Fail: The Origins of Power, Prosperity and Poverty (Profile Books, London, 2012).

109 Anthony King and Ivor Crewe The Blunders of Our Governments (Oneworld Publications, London, 2013). 
"Ideology" means a system of ideas that lies at the basis of political and economic theory. The reason for dealing with these is because of the influence "isms" have on the aims of political decisionmakers. An overlap exists between this segment and the previous one. It is hard to separate the types of government in a state from the ideology that its decision-makers follow. For example, anarchy discussed in the previous segment can be a type of government which the state exhibits. It can also be a political ideology the existence of which people are trying to bring about in a state. ${ }^{110}$

Circumstances change over time. New problems emerge and new demands upon public policy occur. Take climate change for example. It could be ignored. But in that event bad consequences will arrive in time, such as the inundation of houses and property from rising sea levels that science tells us will happen. Economic harm on a wide scale from changing weather patterns will also occur, like fires, flood, drought and hurricanes. Or policies can be adopted to combat climate change. This requires a high level of international cooperation as well as a substantially transformed domestic economy.

Obviously different purposes can be pursued by whatever form of government is adopted. Political ideology plays a big role in policy choices and there are a number of political ideologies that have developed over the years. Some of the more obvious ones are now outlined. Most of these ideologies have as their purpose to make life better for those who live under them. But whether they succeed is sometimes doubtful. Political ideologies vary greatly, for example capitalism and communism. All have their weaknesses and almost none exist in a pure form. Belief in political ideologies is a bit like belief in a religion. It requires leaps of faith.

A caution is in order before looking at political ideology. Views tend to be held with great vehemence and passion by both sides, those in favour or those against a particular ideology. When it comes to competitive politics, this leads to distortions and wild claims often not backed by any real evidence. New Zealanders are not particularly interested in ideology nor do they necessarily believe much of it. It is hard to judge how much they are prepared to act on the basis of its tenets. They seem to be, at least in modern times more in the school of what works, a sort of pragmatism. Nevertheless, historical ideologies sit heavily upon political frameworks and have spawned many political parties, including in New Zealand.

In a democracy there exists more or less constant criticism of government policies. Many of these do not have an ideological element. And at election time ideological differences between political parties tends to be overwhelmed by specific policy promises made by the parties. These are usually couched in terms designed to attract votes. Nevertheless, ideological changes are important. The National Party in New Zealand adopts policies that favour business, farmers and free markets more than Labour. Labour will tend to favour the eradication of poverty, a strong social welfare system of

110 As in the previous section I have not footnoted references to the literature on the source material on political ideology and for the same reason as before. 
support and the protection of workers more than National. On a number of policies, however, there will be agreement between the two main political parties - the importance of free trade and an international rules-based system, for example.

A quaint phrase generated in the 19th century stated in preamble to the New Zealand Constitution Act 1852 (UK) stated that the purpose was to provide for the "peace, order and good government" of New Zealand. This was a common term the British sprinkled around when providing for law-making powers in its colonies. That seems a reasonable aim so long as there is agreement about what amounts to good government, a condition seldom completely attained to everyone's satisfaction. Thus, a framework is created for an on-going contest of ideas.

\section{A Capitalism}

Capitalism is a system for organising the economy. It relies on the ownership of the means of production, distribution and exchange being under the private control of individuals, not the state. The owners keep the profits. Central characteristics of free-market capitalism include the accumulation of wealth, and the existence of competitive markets for the supply of goods and services. Price varies with supply and demand.

Private property is recognised. Markets have to have legal rules that are enforceable. Decisionmaking and investments are determined by every owner of wealth, property or production. Those with capital are the owners. Other people work for the owners. Clashes between capital and labour have been one of the features of capitalism. This led to the philosophy of Karl Marx, who argued that those who were not capitalists had to work for wages and he called them the proletariat.

What is described above is a pure form of capitalism, and it is not often found in the real world. Governments will often intervene in markets to attain what they consider to be desirable social policies. Governments can regulate capitalism in myriad ways. They can regulate it hard or lightly. They may decide to own some of the industries themselves, if it is judged those industries are so vital to the national interest they cannot remain in private hands. Governments have the power to tax and this can be done in a way that the rich pay more tax, thus allowing redistribution by government of some of the wealth. Capitalism in its pure form can lead to a minimalist state with little sense of community.

In modern times, many economies are mixed in the sense they use capitalism to achieve some purposes but not others. States engage in regulation or prohibition of some activities where it is considered the market does not provide an optimal solution. Capitalism can come in many different forms. It may be laissez-faire capitalism with a minimum of state interventions. Or it could be state capitalism where the investment decisions are guided or set by the state.

Capitalist systems with varying degrees of direct government intervention have become dominant in most western countries, and continue to spread. It is often argued that some form of capitalism is better for economic growth than the alternatives. For many countries the vital decision facing 
governments is when to intervene by legislation or otherwise in the market and when to allow the market to remain undisturbed. These are difficult decisions since sometimes the interventions have unexpected effects. Political fashions change over time and what seems a real truth to one generation is frequently later discarded. Politics tends to lack eternal truths. It has changing fashions. In a teleocratic age, the personality of the leaders seems as important as the ideology and the policy. Trust in a person, especially in times of trouble, is important.

\section{B Communism}

The great competitor to capitalism was communism. The ideas behind communism were largely the work of Karl Marx and Fredrich Engels. They developed a theory or system of social organisation in which all property is owned by the community. Each person contributes and receives according to their ability and needs. Then there would be no divisions between classes, all would be equal. The dictatorship of the proletariat was to be achieved by revolution and this would involve violence. The aim was to reduce the poverty and squalor that rapid industrialisation had produced in the nineteenth century Europe.

Communism became a dominant political trend in the international socialist movement in the 1920s after the Russian revolution of 1917 led by Vladimir Lenin. The Soviet model of MarxismLeninism spread after the Second War to much of Eastern Europe and other countries including China. In the contest with capitalism communism lost out, as signalled by the end of the Soviet Union in 1991. Communism withered away in many other countries that had adopted it. The theory sounded attractive, but the reality was different. Many capitalist democracies, however, took on some features of socialism, such a free medical care and a variety of other state provided services.

\section{Socialism}

Socialism is related to communism in terms of the social ends to which it is directed. But the revolutionary aspect present in communism is not present in democratic socialism. Change must arrive via the ballot box. Socialism has many different variants and cover a wide range of different forms of government that give greater or lesser recognition to the need to use the resources of the state to improve the lot of the poor and dispossessed. For example, in New Zealand the Labour Party's constitution states that the party accepts a number of enumerated democratic principles and is a democratic socialist party. Labour is also known as a social democratic party. There are so many varieties of socialism that full description is impossible.

\section{Fascism}

Fascism is a form of extreme right wing government characterised by dictatorial power, forcible suppression of opposition, as well as strong regimentation of society and of the economy. It came to prominence in Europe after World War I first in Italy, then Germany, Spain and Argentina.

Fascists believe democracy is obsolete. Society should be reorganised in a totalitarian one-party state. Strong leadership is required, a dictator leading a martial government. It is necessary to prepare 
for armed conflict and to respond effectively to economic difficulties. Such a state is led by a strong leader. National unity and a stable and orderly society are essential for fascism. Fascists want a mixed economy that aims at economic self-sufficiency.

Fascism uses political techniques to arouse feelings of intense nationalism, and it uses sophisticated propaganda techniques that often tell big lies. It is opposed to liberalism and socialism. Historically fascists have persecuted some groups, particularly Jewish people, and promoted an expansionist nationalist agenda.

\section{E Liberalism}

People who espouse liberal political ideology tend to believe the government's main job is to strike a balance between keeping individuals safe on the one hand and preventing government becoming too big and pervasive so that it is a threat to individual liberty on the other. By liberty is meant that individuals should be free to do what they wish, so long as they do not harm others. Liberalism over the years has taken many different forms in many different countries. When the modern welfare state began in some countries this was taken up by Liberal governments, as with the Old Age Pensions Act in New Zealand in 1898.

\section{F Libertarianism}

This philosophy is related to anarchy discussed above. It upholds liberty as a core principle. Libertarians want the greatest possible political freedom and autonomy. The individual comes first endowed with freedom of choice and voluntary associations not compelled.

\section{G Conservatism}

Conservative parties, of which there are many around the world, including the New Zealand National Party, tend to be committed to traditional values and to oppose change. They usually favour free enterprise, private ownership and may be socially conservative. They respect authority, hierarchy and property rights. They are not usually in favour of big government. The National Party's constitution states among other things that it believes in competitive enterprise, rewards for achievement and limited government.

\section{H Progressivism}

In general terms, progressivism is a political movement that favours reform. Humans have made great progress in science, in technology and in improvement of the conditions in which people live. Change should be pursued. People in different countries identify progressivism in different ways. These days it is about public policies that will lead to positive social change. These include reducing inequality, combating discrimination, improving the environment and intervening to reduce the harsher effects of capitalism. 


\section{Environmentalism}

Some political groups are rapidly emerging around the world concerned primarily with protecting the environment. That has become a purpose of politics and a political ideology has developed around it. The New Zealand Green Party have in their Charter the principle of ecological wisdom. "[T]he basis of ecological wisdom is that human beings are part of the natural world and this world is finite, therefore unlimited material growth is impossible; ecological sustainability is paramount". ${ }^{111}$

\section{J Colonialism}

Colonisation is the policy or practice of acquiring full or partial political control over another country, sending settlers to it and exploiting it economically. Many countries were colonised over a period of centuries by various European countries and others. New Zealand and Australia as well as Canada and the United States were colonised by the British. France, Belgium, Germany, Spain, the Netherlands, Italy and Portugal and others all gathered substantial empires overseas from which they benefitted economically. Whether the countries they colonised benefitted to the same degree remains doubtful. Millions of people in South America, Africa, and parts of Asia lived in colonial societies for centuries and that certainly influenced their culture, their religion and their customs. Most countries ruled as colonies became independent in the years following World War II.

For a big part of its history New Zealand was part of the British Empire, an empire that was enormous and ruled over many parts of the world for several centuries. It was in a way a method of international governance. It was under British colonialism that Europeans settled in New Zealand under the Treaty of Waitangi of 1840 . The journey for New Zealand from colony to independent state was a long and complicated one. It cannot be told here.

\section{K Feminism}

Feminism is an ideology and a range of philosophical responses that critiques the patriarchal social and political structure in society. It has become a political movement that fights for change in how the issue of gender in society is addressed. Feminism has generated an enormous literature and has influenced change social and legal change. It has tended within Western countries to have arrived in three distinct waves. Beginning in the 19th century with the votes for women movement, it moved onto ideas of effective equality and freedom. The third wave has addressed the experiences of transgender and non-binary people.

\section{Bureaucracy}

Bureaucracy is not strictly an ideology but a necessity for all governments of whatever ideology, except perhaps anarchy. Whatever form of government or "ism" people live under, the manner in

111 Green Party of Aotearoa New Zealand Constitution of the Green Party of Aotearoa New Zealand (4 June 2012) at [3.1.1]. 
which decisions are made will usually involve a bureaucracy. China organised a rigorous system of bureaucracy many centuries ago. The public service in New Zealand is a bureaucracy as is the civil service in many countries. An efficient and competent public service is a necessity for any state. The German sociologist Max Weber was the first to formally study bureaucracy as a hierarchical organisation. He found it had a number of characteristics: ${ }^{12}$

- a formal chain of command;

- a fixed area of activity;

- a division of labour;

- the carrying out of assigned tasks;

- decisions and powers are circumscribed by rules and law;

- officials have expert training in their field;

- career advancement dependent on qualifications and merit; and

- qualifications evaluated by merit not by politics.

Bureaucracies were seen to be a necessary and efficient way to actually deliver on the ground decisions made by the state. But private companies have bureaucracies too. There are downsides to bureaucracies - too much read tape, they can be slow in making decisions, and they can be a dampener on innovation and creativity. But, for governments to actually implement their decisions, bureaucracies are essential. Imagine trying to implement the government's Covid-19 policies without public servants - impossible, surely.

\section{THE DIGITAL REVOLUTION}

A discussion of the implications of the digital revolution on politics, political communication and the selection of policies has become essential to understanding how systems of government operate in democracies nowadays. Some of the developments suggest risks of democratic decay and rot. These issues need to be understood and considered by public lawyers.

Isolating the strands that have contributed to the crisis in governance that weigh upon democracies is no easy task. Many of these factors have been considered to be outside the scope of public law and falling within the domain of various social sciences. Yet these developments have changed the way in which politics is conducted, they have changed the nature of political parties, and they have changed the methods of political communication. ${ }^{113}$ They have weakened the traditional media and threatened

112 Keith Tribe (ed and translator) and Max Weber Economy and Society: A New Translation (Harvard University Press, Cambridge 2019).

113 William H Dutton (ed) A Research Agenda for Digital Policy (Edward Elgar, Northampton, 2020); and Election Integrity Partnership The Long Fuse: Misinformation and the 2020 Election (Digital Forensic Lab, Graphhika, Stanford Internet Observatory, UW Center for an Informed Public, 3 March 2021): The report contains an analysis of the production and spread of misinformation culminating in false claims of a "stolen election". 
their business models. On the other hand, it can be seen that the approach of social media systems has been opened up to a wider range of people who have a wider range of views and aims than is reflected in the traditional media. A revolution has been wrought by the digital media. It may not be going too far to suggest that these developments pose for governments more difficult challenges than did the invention of the printing press centuries ago.

At the same time the development of social media platforms such as Facebook, Twitter, YouTube, Reddit and many others have provided the opportunity for the expression of unmediated opinions with no fact checking. ${ }^{114}$ They have provided also the opportunity to express extreme views and conspiracy theories with no accountability for the consequences. The gatekeepers have gone.

New Zealand has learned of these dangers from the terrorist attack by a lone gunman holding extreme views in Christchurch on 15 March 2019. The attack killed 51 Muslim people worshiping in mosques at Christchurch and injured many more. This led to the Christchurch Call in which Prime Minister Jacinda Ardern combined with other foreign leaders to encourage the social media platforms to remove the images uploaded to Facebook by the terrorist depicting the carnage he had wrought. The tragedy has been carefully analysed by a Royal Commission whose report was released on 8 December 2020. ${ }^{115}$

Other features of the digital revolution can be found within the saga of Cambridge Analytica/Facebook data breach and the scandal that ensued with its use in the Brexit referendum in the United Kingdom. ${ }^{116}$ The Russian intelligence agencies, through cyber activity, attempted to influence the outcome of the election in the United States in 2016. ${ }^{117}$ The development of the Internet was thought to have provided new opportunities for connection and engagement with the traditional political processes, enlivening them and promoting a sense of real engagement with politics and decision-makers. Certainly, some of this has taken place. Public authorities engage in their consultations with the public through the Internet and social media platforms.

How the digital media will influence politics in the long term cannot yet be fully known. But there can be little doubt that political decision-makers and the institutions of government are profoundly affected by these changes. New means are available for promoting ideological goals. New means are available for influencing political decision-makers. Truth does not always prevail in these

114 To understand how this is different from what used to occur in the traditional media, read the classic article by Warren Breed "Social Control in the Newsroom: A Functional Analysis" (1954) 33 Social Forces 326;

115 Ko Tō Tātou Kāinga Tēnei: Royal Commission of Inquiry into the Terrorist Attack on Christchurch Masjidain on 15 March 2019, above n 23.

116 See generally "The Cambridge Analystica Files" The Guardian <https://www.theguardian.com>.

117 United States Senate Select Committee on Intelligence Russian Active Measures Campaigns and Interference in the 2016 US Election (United States Senate, Report 116-290, July 2020): The report makes it clear that Moscow was highly active in aggressively interfering. 
engagements. Now there is a crisis in knowing what information to believe and what to discount. Voters are easily confused and do not know what to believe. Rumours are spread frequently through these platforms with deliberate political purpose. Group attitudes and voting preference can be manipulated by algorithms. Against such developments the traditional protections provided in New Zealand by the Electoral Act 1996 are largely impotent. Bad information can be spread, and people make up their own minds what to believe, and the facts tend to be discounted.

Developments in the United States that fed the rise of digital media contributed to political disruption. The role of the Federal Communications Commission as regulator of broadcast media was drastically reduced by the Clinton administration in line with the ideas of Newt Gingrich, having already been weakened during the Reagan administration. The Telecommunications Act 1996 removed the fairness doctrine paving the way for extremism in talk back radio and Fox News. The factors include the decline of the traditional media, the unregulated rise of Silicon Valley entrepreneurs and its giant firms. One result was increased polarisation by making people believe their concerns were not being heard. The new media increased capacity to promote conspiracy theories thorough the Internet. Social media became "a breeding ground for fanaticism, authoritarianism, and nihilism." 118 White supremacy made a resurgence. Twitter became a central means of political communication, troll factories developed. Political polling became unreliable.

\section{THE CHANGED NATURE OF POLITICAL PARTIES}

The implication of the digital revolution for political parties must be considered in public law now. And the decline of mass membership political parties needs to be weighed by public lawyers and understood by the community.

Political parties themselves in New Zealand have changed radically over the past 50 years. A deeply concerning development relating to our political parties flows from declines in their membership. Professor Raymond Miller writes of New Zealand political parties: "Whereas one in four voters once belonged to a political party, today it is closer to two in a hundred." 119 It has been estimated by political scientists that in 1954, 290,000 New Zealanders belonged to political parties, of which there were essentially only two: National and Labour. ${ }^{120}$ This amounted to 26.4 per cent of the votes cast at the general election. By 1984 that was down to 170,000 , or 8.8 per cent of the votes cast; by 2002 they estimated it to be 50,000 , or 2.4 per cent of the votes cast. Now it may be lower. ${ }^{121}$

118 Lepore, above $\mathrm{n} 24$, at 770 . See also $732-738$ and $770-772$ for a history of the media developments and the rise of social media.

119 Raymond Miller Democracy in New Zealand (Auckland University Press, Auckland, 2015) at 175.

120 At 223

121 Ian Marsh and Raymond Miller Democratic Decline and Democratic Renewal:Political Change in Britain, Australia and New Zealand (Cambridge University Press, Cambridge, 2012) at 213-229. 
These days parties are dominated by political elites to a much greater degree. Effective control of the parties is in the hands of a very few people. This is what has been referred to as the iron law of oligarchy. It is for these reasons that political parties cannot be uncritically regarded as the faithful carriers of the public interest and may require greater regulation. Despite this decline in membership, National and Labour remain the two main political parties in terms of voting behaviour in recent elections. But, to a large extent, they are now both cadre parties rather than political parties with a mass membership base. That is to say, they are dominated by an elite group of political activists. This has consequences for citizen engagement with the machinery of government and governance. Fewer people have an involvement with the issues that concern political parties. There was a time when political scientists called the New Zealand system with its strict party discipline, "government by party". ${ }^{122}$ Compared with the situation back then, the parties are greatly hollowed out and not representative of the public at large.

Next comes the issue of campaign and party financing. Funding for political parties tends now to be sourced from corporations, trade unions and wealthy individuals, rather than from mass party membership, which no longer exists. In such a situation, there are risks that the voices of ordinary people will be drowned out by corporate and business interests. Serious issues also exist about funding that derives from foreign sources. The manner in which the funding of political parties by business has developed in the United States has much to do with the present state of political discontent in that country. ${ }^{123}$

The United States has made a radical change in recent years relating to campaign financing. The 2010 decision of the Supreme Court of the United States is anchored in the idea that freedom of expression must be protected. It has been interpreted to allow corporations and wealthy individuals to spend unlimited amounts of money on election campaigns. It has encouraged a most unhealthy relationship between members of Congress and donor corporations. The general perception is that there is a quid-pro-quo arrangement involved. The development results in unrestricted outside spending on political campaigns, by corporations and very rich individuals alike. This is a time when wealth and income disparities in the United States are at high levels. The undemocratic character of this development is obvious and is to be avoided.

Following the constitutional shambles in the United Kingdom that was Brexit, Professor AC Grayling argued that "[t]here should be complete transparency about the funding involved in an

122 Austin Mitchell Government by Party: Parliament and Politics in New Zealand (Whitcombe and Tombs, Christchurch, 1966).

123 Citizens United v Federal Election Commission (2010) 558 US 310. There were earlier cases and the Supreme Court has struck down efforts to reform the system. Plutocracy and politics make an unfortunate combination. Rich people and corporations who donate do not represent majority opinion, but they often prevail. An important book on this subject is Tim Kuhner and Eugene Mazo (eds) Democracy by the People:Reforming Campaign Finance in America (Cambridge University Press, Cambridge, 2018). 
election campaign, not just in the period of the campaign itself but in the research and development of all methods used in campaigning; and a cap on it." ${ }^{124}$ New Zealand law regulates political party funding to some extent, attempts to limit the expenditure of money on elections, and purports to require transparency in political donations. There are ways to avoid many of these requirements. But it should be noted that in New Zealand, at least two of the political parties rely on small online donations to a substantial extent.

Professor Andrew Geddis' book Electoral Law in New Zealand finds there are serious gaps in the law when it comes to regulating party funding and disclosure of donations. He concludes: ${ }^{125}$

... this disclosure regime was so riddled with loopholes as to operate on a virtually voluntary basis; any

donor who wished to keep her or his identity secret could do so easily and completely legally.

The rules are easy to evade. Limits on election expenses imposed by the law have defects in them as well. Yet those who decide on the content of the law are MPs who have more direct interest in the issue than in almost every other matter they legislate on. ${ }^{126}$

The law should require political parties to publicly report their membership numbers periodically so that the public can know to what extent they speak for many, and how extensive their support is. It would also be transparent to require parties to report publicly on their finances and these should be available for public inspection. There is a strong case for changing the law so limits on expenditure extend throughout the electoral cycle.

In many parts of the world political parties are corrupt. Transparency International reports that they are the most corrupt institutions internationally, as found by their surveys. ${ }^{127}$ Many of them, even in Europe, are widely regarded in this way. It would be prudent in New Zealand to ensure that

124 AC Grayling Democracy and its Crisis (Oneworld Publications, London, 2017) at 187.

125 Andrew Geddis Electoral Law in New Zealand: Practice and Policy (2nd ed, LexisNexis NZ, Wellington, 2014) at 156.

126 Despite the statutory entrenchment of six important provisions of the Electoral Act 1996 - the most important of which are the Representation Commission that makes gerrymandering the boundaries of electorates for political advantage impossible and protects the secret ballot - there is a record of substantial political argument about many features of the electoral law between the two major political parties. A recent detailed analytical study of legislative reform to electoral law since 1957 concludes:

[T]hrough a systematic analysis of election reform proposed and enacted since 1957, I have found that partisan election lawmaking is commonplace in New Zealand and that demobilising reforms have occasionally been enacted ... Many components of New Zealand's election system continue to present barriers to full participation.

He calls for serious consideration to be given in New Zealand to a broader array of election reform: See Joshua Ferrer "Re-evaluating consensus in New Zealand election reform" (2021) 72 Political Science 118 at 134.

127 Transparency International "Political Parties are most corrupt Institutions worldwide according to Transparency International Global Corruption Barometer 2004" (press release, 9 December 2004). 
we have sufficient regulation and oversight for political parties to ensure they do not develop in this way, particularly so when the MMP system confers such a central role to political parties. The degree of regulation is too light and the recommendations of the Royal Commission on the Electoral System in 1986 should be revisited, as they were never implemented. ${ }^{128}$ The rules of parties need outside scrutiny. The current provisions about the decisions on party lists and candidates are remarkably loose and unsatisfactory. The room for manipulation is substantial and the courts have not intervened in decisions.

\section{PUBLIC LAW AS AN AUTONOMOUS DISCIPLINE}

All of the segments of this article relate to public law and the nature of the discipline that it is or should be. In this respect Martin Loughlin's contribution adds weight to the points being made.

A striking contribution to public law theory was Martin Loughlin's book The Idea of Public Law published in $2003 .{ }^{129} \mathrm{He}$ argues that public law is an autonomous discipline concerned with the activity of governing. He deals with the twin claims of the state to have the monopoly of the legitimate use of force within its territory but at the same time claiming the ultimate allegiance of its citizens. Public law is the "law relating to the activity of governing" the state." ${ }^{130}$ And he goes on the say that what is involved in the modern state has to be unpacked. The state is a common undertaking and must look after people as a pastor might. This suggests the state is superior to those whose interests it looks after. Yet there is a competing idea that the state is the agent of the people and the rulers function as agents of the people. There is, as Loughlin points out, an unresolved tension between these two notions. Public law has to resolve those tensions. The state must establish a means establishing the rules to provide for order in the state, but also produce the conditions in which governmental authority is established and sustained.

Loughlin goes on to observe that the activity of governing has given birth to a special practice - politics - that is bound up with the activity itself: 131

Politics emerges as a product of contests for authority in government; it arises only when the composition and conduct of governmental authority is debated, criticized and determined. Politics is a consequence of the recognition that the arrangements of government are the result of human choice.

The analysis offered by Loughlin convinces me that the elements of political philosophy and political practice including lobbying, political communication and the dark arts should be taught to

128 Royal Commission of Inquiry into the Electoral System Towards a Better Democracy: report of the Royal Commission on the Electoral System (House of Representatives, December 1986).

129 Martin Loughlin The Idea of Public Law (Oxford University Press, Oxford, 2003). I would prefer the term interdisciplinary to autonomous.

130 At 152 .

131 At 155. 
public law students so they can secure sufficient knowledge to be able to understand how the system works. I recall how surprised I was when leaving Parliament to find how so many practising lawyers regarded Parliament as a black box where statutes and decisions emerged, but most of the legal profession in 1990 had little understanding of the processes within the executive branch of government that led to these decisions.

The process of politics and competitive political parties with the choices they offer must be studied and understood to have any real appreciation of how public law works. Conflict has to be resolved and differences of opinion accommodated as far as possible. Yet partisanship has to be moderated, Loughlin argues, and that occurs by institutional forms of government that involve careful deliberation on decisions. The process strengthens confidence and allegiance. He observes, "the establishment of a law-governed state is a means of generating political power. In this sphere, formal constraints are often enabling." ${ }^{132}$ Wider political practice governs. Public law, he says, is a form of political discourse. There can be, he argues, no fixed foundations to the practices of politics. Political reality exists only through representation. Public offices are vital in this respect. Political power is projected through collective action.

The analysis then goes on to use the concept of constituent power, which is recognition that government is instituted by and for the people. Democracy and positive law exist in tension. And the tension is mediated through constituent power. This assists in identifying more clearly the purpose of modern constitutions. These constitutions are ways of organising and generating power, and they confer authority thereby. Power always remains subject to political pressures for change. Loughlin also argues that human rights jurisprudence has meant that constitutional adjudication extends to cover a broad range of government activities and so the judiciary increasingly adopts what he calls a political jurisdiction.

Professor Loughlin goes on to argue that the activity of governing is: ${ }^{133}$

... best conceived as political jurisprudence ... Public law is a form of political jurisprudence that incorporates no transcendental or metaphysical ideas of justice and goodness; it is concerned solely with those precepts of conduct that have evolved through political practice to ensure the maintenance of the public realm as an autonomous entity.

This leads to the conclusion that "Public law is a form of political reason that is best expressed as reason of state." 134 While public law revolves around a core of principles, their application remains

132 At 156

133 At 163

134 At 163 
indeterminate. Decision makers are obliged to adhere to law as a prudential necessity. Public law is a form of political reasoning driven by prudential considerations.

I am not concerned here with weaknesses that may exist in the pure theory that Loughlin advances. The critical point is the emphasis the theory places on interdisciplinary investigations into the foundational elements that underpin the modern state. And more particularly, what that may mean for the teaching and practise of public law at a time that democracy is under some degree of global challenge. The endless emphasis of public law on courts and theories of judicial review seems to me counterproductive. The courts do not hold and will never hold the primary levers of power in government. ${ }^{135}$ It is upon the exercise of those levers and the activities of those who control them to which attention should shift. Loughlin's omission of any serious consideration of international law is an issue for countries like New Zealand that are heavily dependent on an international rules-based system.

\section{CONCLUSION}

A new approach to New Zealand public law and citizenship education means taking a hard look at politics. Such an approach also involves understanding the manipulation of public opinion resulting from the digital revolution, the techniques by which public opinion is formed and what influences it. It means understanding the working of political parties and how elections work. Parliament, its Standing Orders, the activities of its Select Committees require more attention. Understanding the Cabinet, its committee system and the public service policy generation and administrative systems, along with the Cabinet Manual 2017, is essential. This means becoming literate with the New Zealand political culture and political practice. It means breaking down the artificial distinction between what is statute law, common law, and convention or custom. It is what happens that matters. It would also be appropriate to teach in the schools the basic elements of the legal system, the hierarchy of courts, how the judicial process works and the main elements of the criminal law. This would help to enhance the rule of law's value. ${ }^{136}$

All of the above presages a more contextual and interdisciplinary approach to public law and citizenship education. It is one that concentrates upon how the New Zealand system works in fact. This involves exploring some foundational issues concerning the state, its powers, its form of organisation, some political philosophy, the influence of ideologies, and a systematic study of the political practice. It requires more institutional study of politics, its processes and the techniques of political management than appears to be carried out now. Social media, the internet, fake news and

135 Geoffrey Palmer "Can Judges Make a Difference? The Scope for Judicial Decisions on Climate Change in New Zealand Domestic Law" (2018) 49 VUWLR 191.

136 The Secret Barrister Fake Law: The Truth about Justice in an Age of Lies (Picador, London, 2020). While many of the features outlined in the book are not present in New Zealand, namely inaccurate tabloid journalism, the features of the legal system in New Zealand appear to be less well known than once they were. 
the threats to the business model of the traditional media have all changed the way politics in New Zealand is conducted.

Public law should concentrate on New Zealand institutions, New Zealand politics and New Zealand problems. The example of the two major Anglophone democracies to which New Zealand historically has related do not offer the comfort that once they did. We need a broader approach incorporating the lessons from the social sciences. We need to understand how public law, like all law, is a human construct and must accommodate politics. In this article I have but touched the surface of the issues. And it is to our own history and political culture we need to look to fashion remedies for the problems of colonialism that continue to exist. For this, exposure to some early New Zealand history, particularly relating to the Treaty of Waitangi and tikanga Māori and its place in our constitution and law is essential. The New Zealand Wars and land confiscations can only be understood in the context that the Crown went to war to secure powers that Māori did not believe they had given up in the Treaty. The case is also made in this article for significantly increasing the level of general education about how the New Zealand government works and the level of political literacy in the population. This will assist in strengthening support for democracy at a time when it is under challenge.

A properly educated population can help a great deal. Informed citizens can help democracy to work and there is an emerging literature on the topic. ${ }^{137}$ The blessings of a liberal democracy are substantial, but they can easily slip and slide away. ${ }^{138}$ New Zealand needs a better articulated public philosophy. ${ }^{139}$ It is important to be positive and hopeful. ${ }^{140}$

137 Henry Milner Civic Literacy: How Informed Citizens Make Democracy Work (University Press of New England, Hanover, 2002); and David Van Reybrouck Against Elections: The Case for Democracy (The Bodley Head, London, 2013).

138 The author was a student of Constitutional and Administrative Law at Victoria University in 1963 in which the prescribed text was Sir Ivor Jennings The Law and the Constitution (5th ed, University of London Press, London, 1959). It was concerned with the British Constitution. We learned nothing about the Treaty of Waitangi. The implication was that our constitutional arrangements were the same as those in London, which was not true then and is even less true now. K J Keith - then a young lecturer - did teach us about administrative law and particularly the great decision of Ridge v Baldwin [1964] AC 40, about which he later wrote a much read article: Kenneth Keith "Ridge v Baldwin - Twenty Years On" (1983) 12 VUWLR 239.

139 Walter Lippmann The Public Philosophy (Mentor Books, New York,1956). Constitutionalism at a global scale can be approached by "conceiving of the cosmopolitan constitution as a national constitution that submits its operations to the supervision of international peer institutions": see Alexander Somek The Cosmopolitan Constitution (Oxford University Press, Oxford, 2014) at preface.

140 Jonathan Sacks The Politics of Hope (Jonathan Cape, London, 1997). This book stresses the need for social cohesion and searching for the common good. 
